Portland State University

PDXScholar

$5-1-1970$

\title{
Italy 1830-1848: the role of the press and the theatre in the formation of the national spirit
}

Albert Louis Cereghino

Portland State University

Follow this and additional works at: https://pdxscholar.library.pdx.edu/open_access_etds

Let us know how access to this document benefits you.

\section{Recommended Citation}

Cereghino, Albert Louis, "Italy 1830-1848: the role of the press and the theatre in the formation of the national spirit" (1970). Dissertations and Theses. Paper 935.

https://doi.org/10.15760/etd.935

This Thesis is brought to you for free and open access. It has been accepted for inclusion in Dissertations and Theses by an authorized administrator of PDXScholar. Please contact us if we can make this document more accessible: pdxscholar@pdx.edu. 


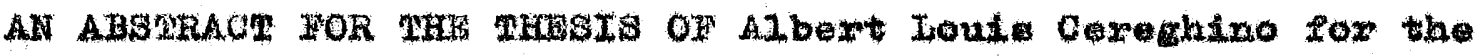
Mater of Anto in Hetory preanted Apri1 27, 1970.

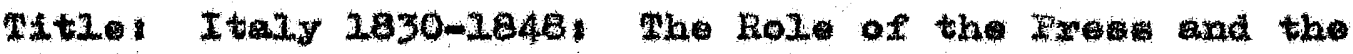
Wheatwe in the Fomation of the National splwit.

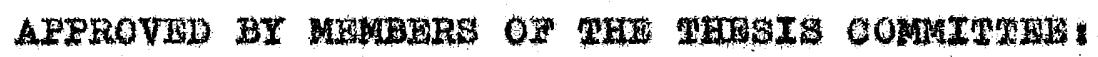

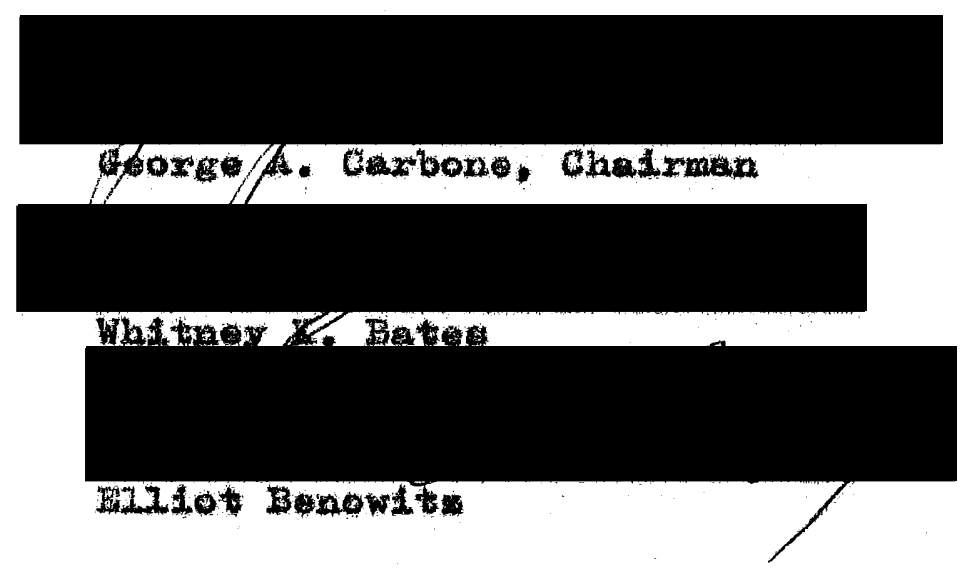

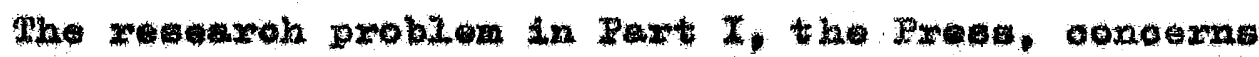

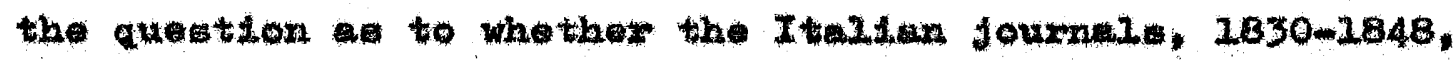
wexe fflonotous in the foxmation of the Itelitar nationa

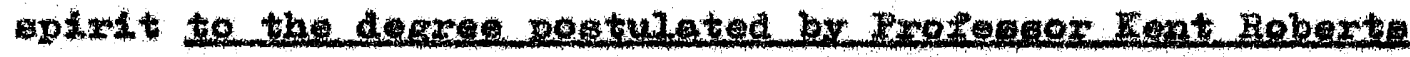

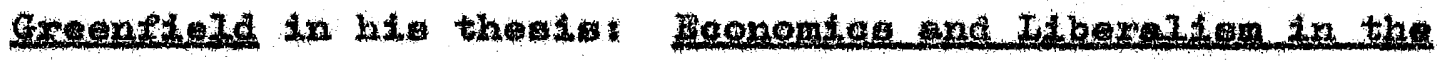

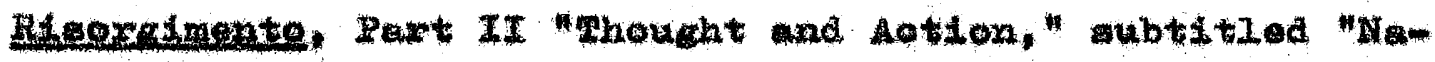

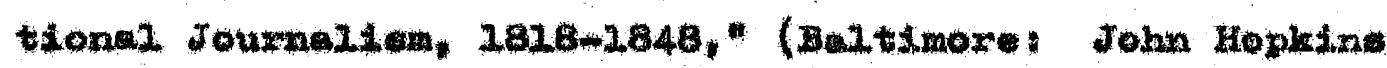

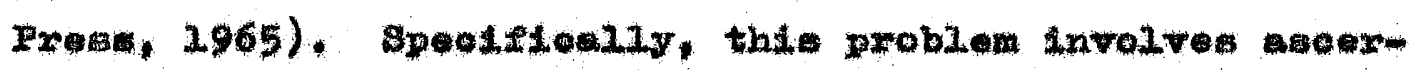

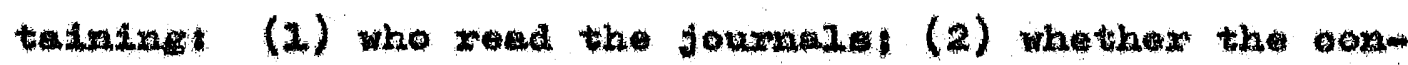

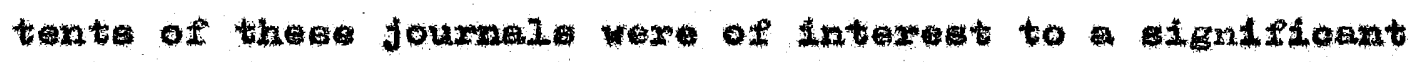
poxtion of the population of tho estat toteal and (3) whothow the fournale were disseminated to any appreclable do- 


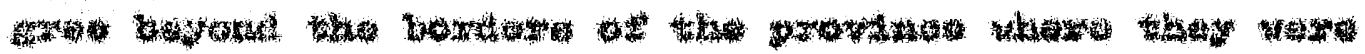

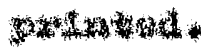

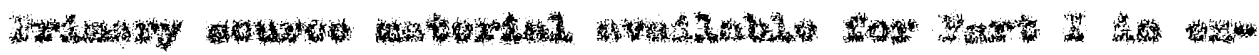

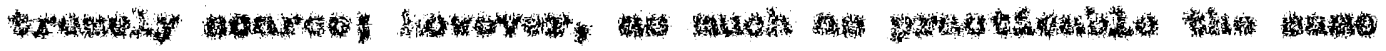

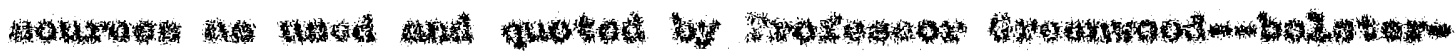

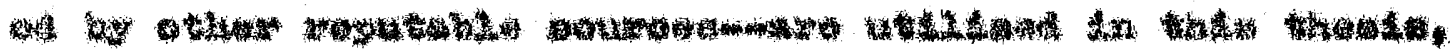

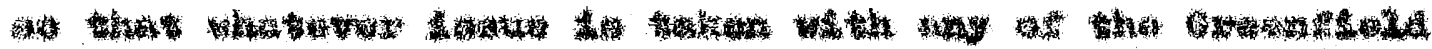

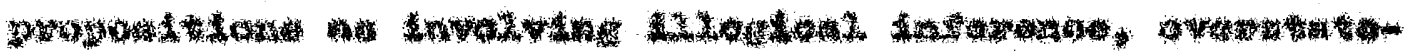

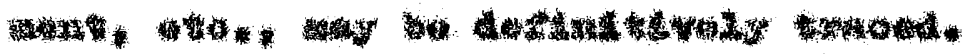

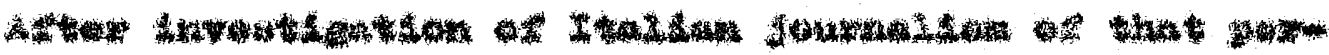
40h.

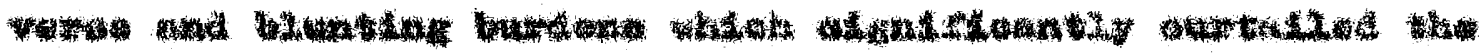

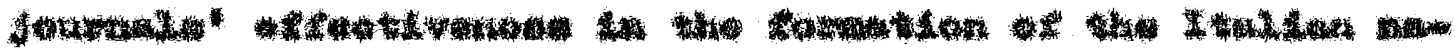

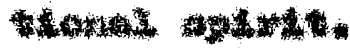

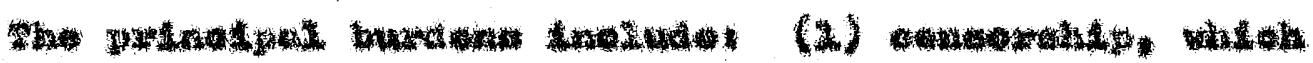

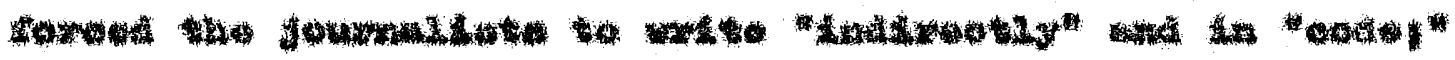

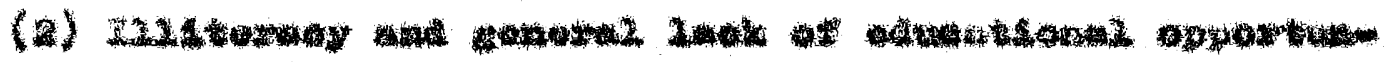

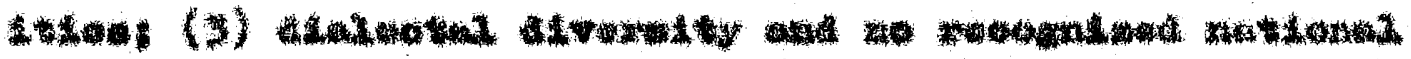

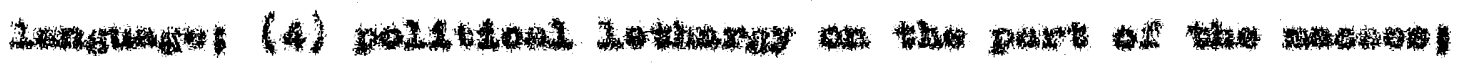

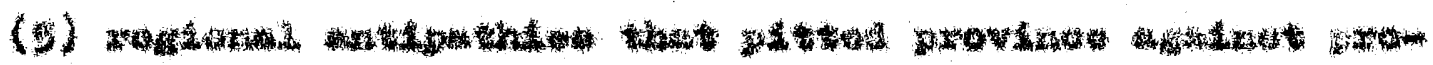

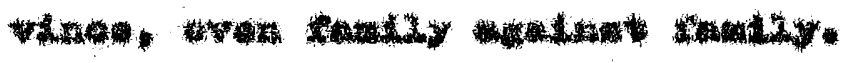

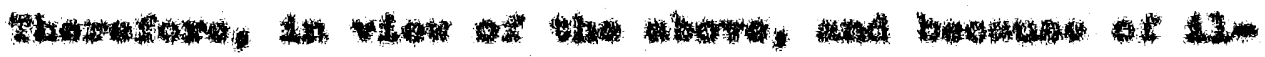

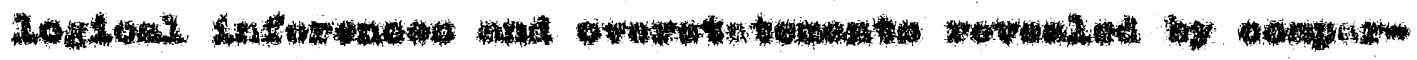

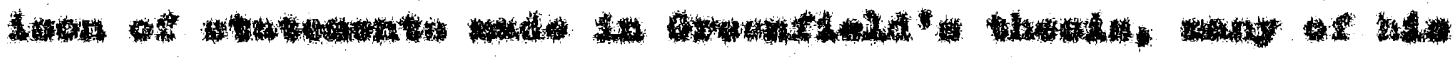

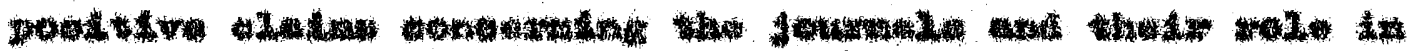

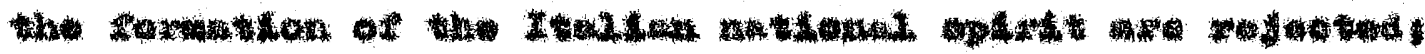


to that extent the Grenfleld then is onervated.

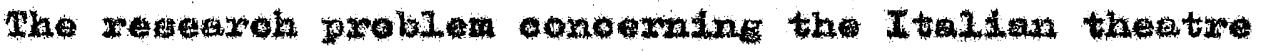
(which Ineludeg both tragedy and opara) inrolver detemain

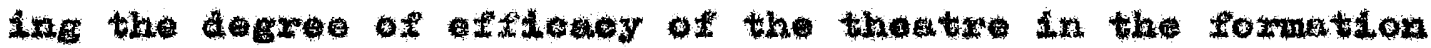
of the Italian national opirit, 1830-1848.

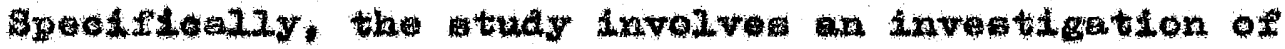
the hardehip wader whidh the thatue operated. These In-

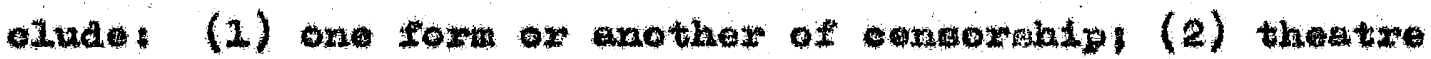

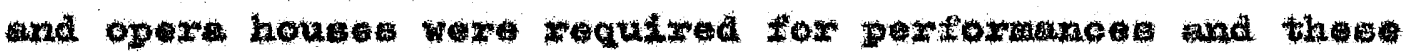
were found only in the olties whexe alnoxty of the pop-

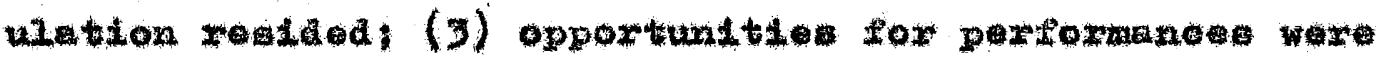
Heanal mot of the time.

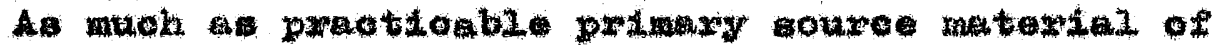

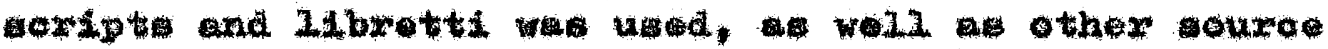

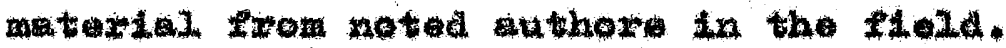

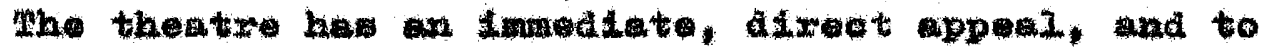

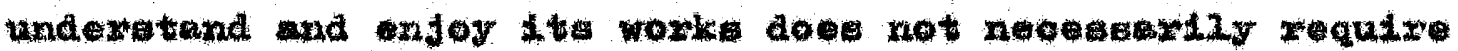

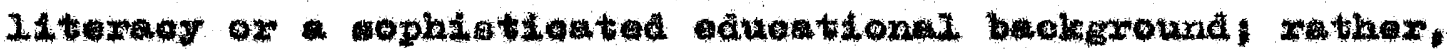
1t demand on the part of the audience an Intendty of foci-

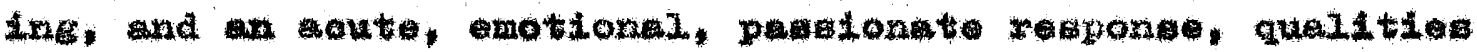

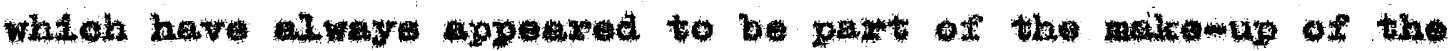
Ital1an poople.

Wherefore: (1) in viev of the wevel (2) beowa the

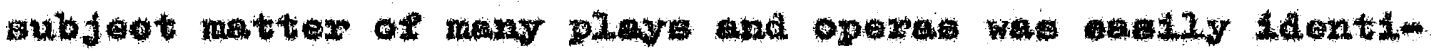

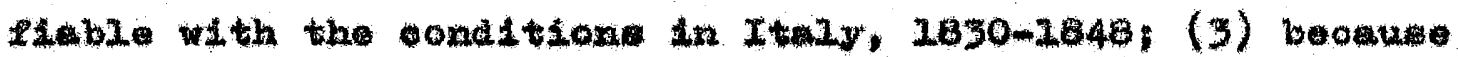
of the many denonetration thet follow theatried partomm- 


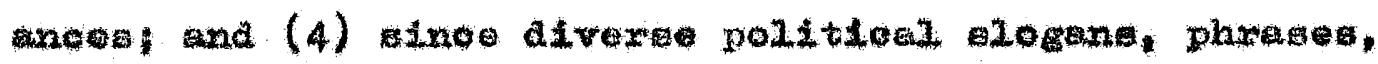

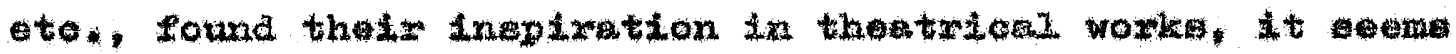

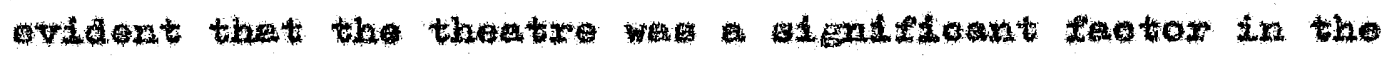
formation ox the Italitan national eptrit, $1830-1848$. 


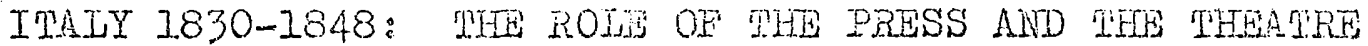

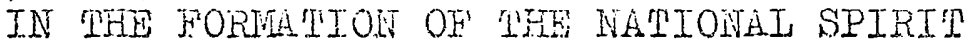

By

ALBERT LOUIS CAREGHINO

A thesis submitted in partial fulfillment of the requirements for the degree of

MASTER OF ARTS

in

HIS'TORY

Portiand State University

1970 
TO THE OFFICE OF GRADUATE STUDIIS:

The members of the Committee approve the thesis of Albert Louis Cereghino presented April 9, 1970.

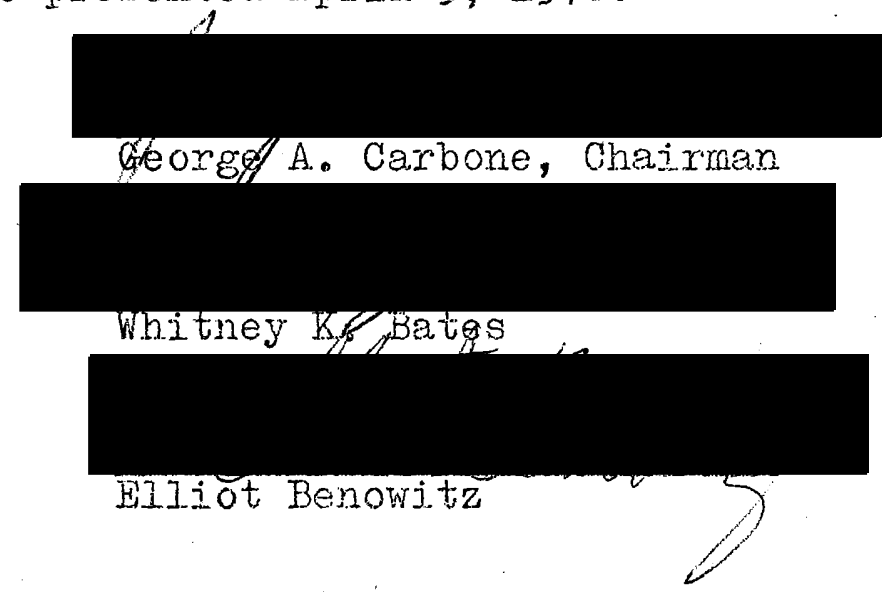

A.PPROVED:

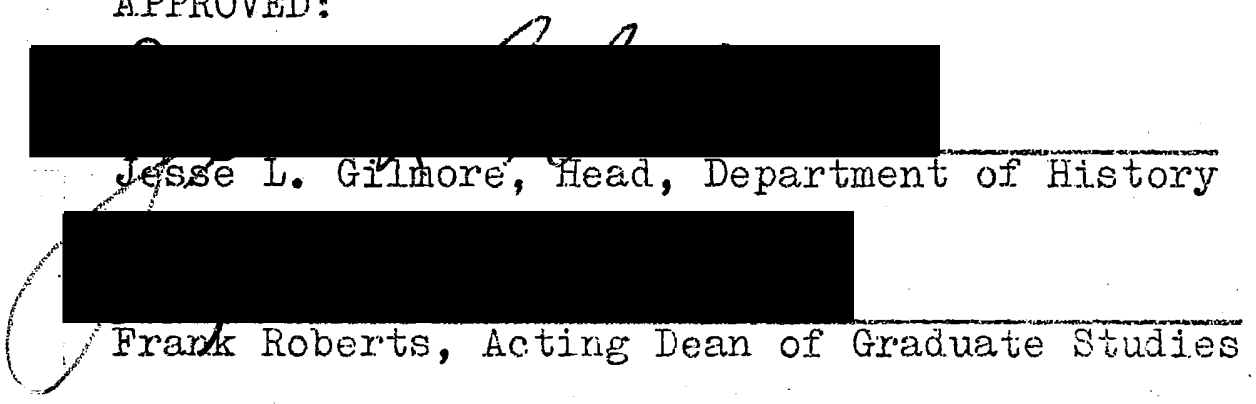

May 7,1970 
TABLE OF CONTENTS

PAGE

PART I THE PRESS 1

CHAPTER

I INMRODUCTION $: 1$.

Definition 3

Brief Survey: 1815-1848 3

II THE PRESS PROBLEM: AN ANALYSIS 12

Censorship 12

Education 20

Language $\quad 30$

Lethargy $\quad 35$

Regional Antipathies

III THE GREEITEIEID THESIS $4 I$

Discrepancies 44

IV CONCLUSIONS 58

$\begin{array}{ll}\text { Summary } & 58\end{array}$

Conclusions $\quad 59$

PART II THE MHEATRE 63

CHAPPER

I INTRODUCTION $\quad 63$

Definition $\quad 66$

Brief Survey 67 
CHAPPER

Drama: Alfieri to 1848

Opera: $1829-1848$

II THE THEATRE PROBLEM: AN ANAIYSTS

Censorship and Related Problerns

Drama

Opera

Attendance and Performances

III CONCLUSIONS

Summary

113

Conclusions

114

BIBIIOGRAPHY 


\section{PARI I THE PRESS}

\section{CHAPLEIR I}

\section{INTRODUCTION}

Part I of this paper does not dispute the fact that during the period 1830-1848, there was in Lombardy, and to a lesser extent in the rest of northern Italy, those who closely watched and commented upon a series of economis and social changes taking place in Europe and elsewhere. Nor does it take issue with the fact that some of them did use with some degree of effectiveness public journals to repoxt facts and express their opinions-however indirectlyomir a kind of understood conspiracy. Finally, this paper does not quarrel with the proposition that in their writings they recognized a necessary relation between econonic and social. progress and the engendering of action leading towards poIitical emancipation. Rather, Part I questions the degree of effectiveness of the journals in helping to form the Italian national spirit. Particularly, this paper rejects some of the positive claims put forth by Professor Kent Roberts Greenfield ${ }^{1}$ in his thesis on the subject, which the reader is invited to study, in oraer to be in a better po-

1 Kent Roberts Greenfield, Economics and Liberalism in the Risorgimento (Baltimore: The Johns Hopkins Press, 1965 ). 
sition to evaluate points put forth in Part I of this paper. The process of determining the degree of effectiveness of the printed word on the minds of men-mingly or collectively-anvolves at best abstractive qualities difficult to ascertain and measure with any great reassurance of certitude. "It is difficult to deternine the immediate results of a periodical." 2 It is even more difficult to determine the long-range results.

Too, in the case of the Italian peninsula, 1830-1848, the appraisal must reach across the viaduct of years-ment over a century--to a land then divided and dormant and to a. time when records kept, especially those of the press, were and still are today, largely subjective, inconsistent, fragmentary anỏ in many cases non-existent.

However, some conclusions on "Italian national. journalism" can be reached, even on the basis of the meagex information extant, if reasonableness and judicious logic are invoked in assembling evidence, drawing inferences thexefrom, making comparisons and then forming judgrents leading to conclusions.

When access to primary source material was impossible, effort was made to use such source material as indicated by the Greenfield thesis, so that any discrepancy of inference and conclusion postulated by this paper could be referred back to the very information and figures utilized in that

$$
{ }^{2} \text { Greenfield, op. cit. , p. } 185 .
$$


thesis; this process was also reinforced by reference to other material as well.

Since there was in the period 1830 w 1848 a well defined exchange of ideas among a small group of Lombard journalists, as postulated by the Greenfield thesis, their writings can be studied as somewhat typical of the even smaller. group of liberal thinkers in the rest of noxthern Italy.

\section{DEFINITION}

For purposes of this paper, the term, "press," defined as "...printed publications collectively, especially newspapers and periodical.s..." ${ }^{3}$ is used synonymously with the term "journalism."

\section{BRIEF SURVEY: $1815-1848$}

Napoleon's disastrous retreat from Moscow and his subsequent defeat and exile ended an era. The 1815 Treaty of Vienna imposed the reactionary influence of Austria on Europe and restored autocrats wherever possible. Fearful of what might happen as the result of "republicanism," the respective rulers imposed, in varying degrees, most drastic controls of the press.

In the first half of the 19th century the press in Italy was almost non-existent, and the profession of journalism might well have been scheduled as a dangerous occupa- 
tion. "Italian journalism emerged late in the history of the Peninsulia."4

In the era after 181.5 in the eight states of the Peninsula, which included the Austrian provinces of LombardyVenetia, and the "independent" states of Riedmont, Tuscany, Parma, Iucca, Modena, the Papal States, and the Kingdorn of Naples and Sicily, there were, all told, some ninety publications. A single official gazzette ("privileged," official), which each state supported, contained government announcements and such other materiel. as each government thought fit to publish; naturally, the activities of these governments were always reported in a favorable light. in adition, there were a few "family" papers, trade journals, or what was also called jourmals of useful knowledge (cognizioni utili) publications closely akin to almanacs, reviews of one kind or another, and ecclesiastical publications.

This was the extent of journalism--there was no newspaper as it is known today published in that period-muntil 1847 when the first "free" newspapex was founded in northern Italy, in Piedmont, by Count Cavour, called Il Risorgimento, which gave the pexiod its name.

It was not until 1847, for example, that a genuine magazine, Predari's Antologia, was permitted in Piedmont; and the fate of the Lombard Conciliatore and the Florentine Antologia, both suppressed by the Austrian authorities directiy or indirectly, was plain

${ }^{4}$ Kenneth E. Olson, whe History Makers (Baton Rouge: Iouisiana State. University Press, 1966), p. 231. 
evidence of the severity of the censorship. 5

The Conciliatore, 1818-1819, was an audacious journal for its time. It was founded by the dramatist Silvio Pellico, "...its soul and life..., "n together with the Milanese Counts Iugi Porro-Iambertenghi and Federico Confalonieri, and it burst upon the scene with promise and brilliance. "I'Italia si applaude d'aver data la Iuce a Galileo..." (Italy applauds herself that she gave light to Galileo), 7 proclaimed the Conciliatore in an indirect blast against gorernraent oppression.

In a sense, the Conciliatore car be called the forerunner of several journals that tried in their own way to extend liberal thought. Among other things, this journal "... was the first Italian review to champion Romanticisn, together with many of that philosophy's overtones of notionalism and independence: "8 ... It tried to awaken its readers to the great advantages of economic and scientific advancements, of public education and of lay philanthropic associations; perhaps most significant of all, its editors were not above using witticisms to make political allusions. The Conciliatore was bound to arouse the Austrian government's ire. It

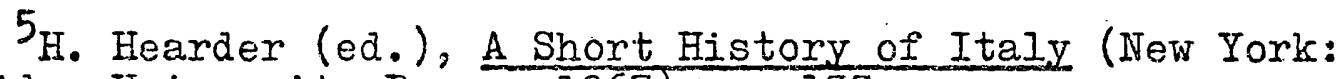
Cambridge University Press, 1967), p. 133.

${ }^{6}$ F. Cazzamini-Mussi, Il Giornalismo a Milano (Milano: Familglia Meneghina Editrice, 1934), p. 287 .

7 Renato Soriga (ed.), Pagine Inedite del Conciliatore (Milano: Tipografia Antonio Cordani, 1930), p. 6 .

$8_{\mathrm{H}}$. W. Boynton, Journalism and Literature (New York: Houghton Mifflin Co., 1904), p. 4I. 
was "...repeatediy maimed and mutilated by the censor, and in mid-October, 1819, was abandoned."9

In spite of the repressive action of the government, and its continued surveillance, a determined and not altogether unsuccessful effort was made in Lombardy to produce what might be loosely termed a patriotic journal.

In 1827, the editorship of Lampato's journal with the bland but ponderous title of Annali universali di statistica, economia pubblica, storia e commer cio, was turned over to the editorship of $G$. D. Romagnosi, reputed to be one $8^{f}$ the finest intellects in Italy at that time.

Through the Annali Romagnosi sought to draw Italy from the condition of backwardness and isolation to the high road of European progress, not by means of historical compaxison like the Romantics nor by Mazzinian uprisings, but by the forbidding road of political economy, trade statistics and industrial information and promotion.

Romagnosi turned all his attention to the industrial progress of France and England and largely ignored Austria, in his comparisons with the state of affairs in Italy.

He gathered round him a group of able assistants, Carjo Cattaneo, Cesare Correnti and others, and set to wori to create a well informed and interested public opinion bent on the economic and industrial revival of Italy. It [talics mine]

After some ten years as editor, Romagnosi died, but the

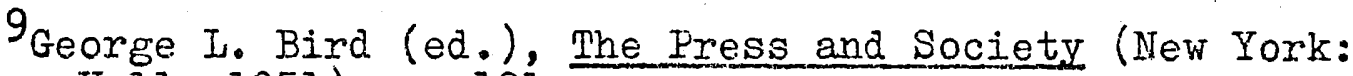
Prentice-Hall, 1951), p. 121.

10 Francesco Fattorello, "Giomale," Enciclopedia Italiana ed. Giovanni Gentile, XVII, p. 284 (1933).

IIArthur J. Whyte, Evolution of Modern Italy (Oxford: Basil Blackwell. Co., Itd., 1950), p. 43. 
Annali went on, and out of it grew the two other great Lombard publications: Battaglia's Rivista europea, 1838 , and Cattaneo's Politecnico, 1839.

As proclaimed by its title, the Rivista europea's format was to be European in scope, and, rather unsuccessfully, sought whenever possible to present to its readers the best Italy could produce by means of original contributions from living writers or by reviews of their works. The great Italian writers of the past were celebrated and of ten compared with the best that was being produced in other countries.

Carlo Cattaneo in 1839 founded the third in this ser.. ies of principal Lombard journals called the Politecnico.

Cattaneo declared in his Introduction that the supreme purpose of the jourmal would be the prompt diffusion of scientific knowledge to meet the pressing needs of contemporary Italian life, and particu-larly 2 the need of promoting every maniner of indus-

But, unfortunately for efforts to develop the national spirit, Cattaneo was never a netionalist in the unitary sense, and he devoted much space in his journal to purely Lombard matters, revealing no great penchant for relating Lombardy's needs and problems to those of other states of Italy. However, "...Cattaneo's work was marked by bold imagination ana courage in criticism."13 His pervasive knowledge gave to Politecnico a scholarliness perhaps surprassing at times even that of Romagnosi's Annali.

$12_{\text {Greenfield, op.cit., p. } 184 .}$
$13_{\text {Fatiorello, op.cit., p. } 186 .}$ 
The other publications, such as the I'Ape delle cognizioni, 1833, the Economista, 1841, and the Spettatore industriale, 1844, of the trade jouranl line were useful but of little value in the formation of the rational spirit. It was the same with business journals, such as the Eco della Borsa, 1839, and related publications. So-called journals of "pastime," or of the salon, such as I teatri, Corriere delle dame, both founded in 1833; Giornale di novita artis-: tiche, letterarie e teatrali, 1833, and the Pirata, 1840, among cthers, were mostly for the leisured axistocracy ard of ephemeral value. The first pictorial periodical at Milan was the Cosmorama pittorico, founded in 1835; it brought to its subscribers illustrations of physics, chemistry, mechanical devices, etc, and attained some popularity, but its subject matter in time became quite literary and its il.w lustrations so new and involved that they were of ten unintelligible to many of the literate people.

There were papers in the other states of Italy as weIl, but with the exception of those founded after the lifting of some of the restrictions of the press after 1847 , they were generally of no value in helping to form the national spirit. In Genoa, for example, in 1828, G. Mazzini founded under licerse the pronising I'Indicatore Genovese, and in 1829 he founded in Leghorn I'Indicatore Livornese, also under Iicense. However, both papers had but a brief life because of the ant1government attitude of Mazzini which invariably showed in his writings: 
The Papal. States had some twelve papers which, before 1847, were highly conservative in character, devoid of any political news, and almost exclusively devoted to ecclesiastjcal matters.

G. P. Vieusseux's Antologia, founded in F'lorence in 1821, was worthy of praise. The Duchy of Iuscany was relatively mild in its censorship; therefore, the Antologia was able to flourish. It came out regularly at the first of the month and was generally regarded as liberal.

It was inevitable that the Antologia would occupy itself with political arguments, irrespective of its initial announcement that $i_{4} t$ promised a journal of letters, science and art.

Cuts, suppressions and Jimitations sometimes interferred with the publication of Vieusseux's Antologia; however, some things did manage to pass, some discrete allusions, some comparisons of the present with the past. The censor would sometimes prom hibjt innocent allusions, and would let others not so innocent to pass.

Another form of "journalism" which became somewhat popular were the almanacs or strenne, circulated on the firsti of the year. The strenne ranged in form all the way from the cheap farmer's almanac to the very expensive and elaborate literary ones which the well-to-do presented to each other as a New Year's greeting. The jouranlists at first repeatedly criticized the poor almanacs for the quackery and cheap

${ }^{14}$ Cesare Spellanzon, Storja del Risorgimento e dell: Unita. Vol. II: Da dopo i moti del 1.820-21 alla elezione di Papa Pio IX 1846 (Milano: Rizzoli and Co., 1934), p. 555. 
romance which they dispensed to the poor, or satirized the expensive ones for their elaborate irivolity. But soon they understood the use to which both kinds could be turned as a means of communicating sound and usefu] information and as an aid in ".."quickening a patriotjc consciousness." 15 The Presagio, 1835, was one that realized for a time the liberal ideal, and it was published by several young men among whom could be counted some of the founders of Rivista europea.

The liberal and patriotic ideal of the strenna was embodied in the famous lipote della Vesta Verde which Cew sare Correnti slipped past the censor and published, in $1847 \mathrm{~m}$ 48. "It contained in popularized form the whole program of the liberal journals of the time...,"16 from accounts of popm ular schools and charities to a discussion of the railroad.

The clandestine press, mostly published abroad and smuggled into Italy with great difficulty and danger has not been considered in the Greenfield thesis. However, some mention of it ought to be made. Notwithstanding the fact. that papers, such as Mazzini's Young Italy, I832, I'Apostolato popolare, 1840, and others were published sporadical.Iy and on meager budgets with the ever-prevailing uncertainty of circulation, the outlawed press should be given some credit for disseminating ideas leading to the formation of the national spirit, however small and ephemeral that influence

$$
\begin{aligned}
& { }^{15} \text { Cazzamini-Mussi, op.cit., p. } 292 . \\
& 16 \text { Greenfield, op.cit., p. } 229 .
\end{aligned}
$$


might have been. Some indication of its effectiveness may be seen by the punitive measures taken by the various governments in Italy ageinst those found. with the dreaded publications on their person:
...it became an offense to have a copy of Young Italy in one's possession, and this prohibition was of the greatest advertising value. The Pied-- mont government condemned to a fine and two years imprisonment anyone guilty of not denouncing a membex of Young Italy...the small $I_{1}$ ghipments of Marseilles ran short of demand...
However, "...Mazzini as late as 1839 was writing only to a few of his disciples who had remained iaithful." l8

17 Stringfellow Barr, Mazzini (New York: Henry Holt and Co., 1935), p. 47.

${ }^{18}$ Spellanzon, op.cit., p. 814. 


\section{CHAPTER II}

THE PRESS PROBIEM: AN ANALYSTS

For purposes of this paper, the press problem, 18302848, is viewed as multiple, involving finding out, among other things, who was, and to what extent there was a reading public, whether or not a message of nationalistic impor. tance was being communicated which materially contribuied to the formation of the Italian national spirit- Io the degree of effectiveness postulated by the Greenfield thesis.

\section{CENSORSHTP}

Of course, "the greatest deterrent to any political. journalisn at this time was the most effective censorship and the punishment which awaited the violator."19 Both varm ied according to the laws of each individual state.

Generally speaking, securing a license to publish a journal of any kind was very difficult; among othex requirements, the authorities "...insisted that an editor have a politically impeccable past." 20 Practically his whole life was investigated, and the least suspicious happening or utterance resulted in summary denial of license.

${ }^{19}$ Geoffrey Trease, The Italian Story (New York: Vanguard Press, 1963), p. 48 .

20. W. Crawley (ed.), The New Cambridge Modern History (Cambridge: University Press, 1965), p. 431. 
In all eight states of the Peninsula, the shadow of the censor loomed nearby, ever ferretting out of copy all phrases, slogans, epithets that might even remotely smack of "liberalism," Italian constitutionalism or nationhood; and "...as for the words, 'liberty' or 'liberal,' they were generally forbidden." 21

On many different levels the interference in people's private lives was continuous.

Practically everywhere letters were opened by the police, and the only other means of outside communication-me newspaper-was goveminent owned.

In Piedmont, the Church hierarchy, as well as the government, exercised censorship over all printed matter, particularly periodicals, and "...until the reforms of the 40 's eased the way, the path of learning was strewn with every obstacle that timidity and prejudice could accumulate."23 Cavour, who was a native of Piedmont and spent many years of his life there, but with years of training and study abroad, is reported as having remarked that the Savoy Kingdom was a "...kind of intellectual hell." 24

The government of Tuscany appears to have been one of

21 Pricilia Robertson, Revolutions of 1848 (New York: Harper Torchbooks, 1952), p. 325 .

22 Marjorie Strachey, Mazzini, Garibaldi and Cavour (New York: Stackpole and Sons, 1938), p. 11. 23 Bolton King, A History of Italian Unity (London: James Nisbet \& Co., Itt., 1899), p. 47 .

${ }^{24}$ Ibid., p. $16 \dot{3}$. 
the very few which was willingly accepted by its subjects; necessarily, there was some rapport between government and citizen, which was partIy reflected in the comparatively mild censorship, "...as long as one did not cry too loudly."25 Nevertheless, the government suffered little criticism of itself by the press or otherwise. What would orainarily be considered prohibited books and journals, however, vere from time to time sold openly on the bookstalls; nonw Tuscan literature was adnjtted rather freely but sporadically according to the whim of the censor.

Vieusseux's library at Florence was the only place in the Peninsula where men so disposed could meet to discuss political questions, or if they were literate, to read the leading European journals.

Even though Tuscany was one of the more prosperous states and sometimes mild in its censorship, Gino Capponi said of it that "...it was a Garden of Paradise without the truth of knowledge and without the tree of life." 26

In the case of the Austrian provinces of LombardyVenetia, the chief censorial tribune was in Vienna on which were dependent provincial inspectors with very linited powers. There were, of course, no political newspapers as such, with the exception of the "privileged" gazzettes of Milan and Venice, which were composed in the government offices.

${ }^{25}$ Spelianzon, op.cit., p. 147.

26 Gino Capponi, Scritti editi e inediti (Florence: 1877), p. 14, quoted in King, op.cit., p. 69... 
The police in Iombardy-Venetia after censorship was restored by law in 1815 had the right to suspend for 3 months all periodicals against 'reli-. gion an the public good' after two written. warn-ings.

Longer suspensions were decided by the Council of Ministers in Vienna, and the process of getting a response from it literally took months.

It was in Iombardy where the liberal vriters appeared in larger numbers, and where, under the sometimes stringent censorship, they were forced to report indirectiy and covertly in the leaded language of statistics and in descriptions of English, French, etc., econonic and techrological advancements, e.g., in the Amali and the Politecnico. They hoped in so doing to reveal the Feninsula's backwardness in those areas, with the long-range view of pointing up the advantages of free trade and free association, and the increasing elimination of many different kinds of divisive barriers. Also, by reviewing some of the literary output of Furopean countries, the Rivista europea, particularly, hoped to inspire and engender some native literature; it hoped to put across the idea that art was inseparable from the other processes of civilized living, and that advancement of Ital-ian civilization in the 19th century required the dynamic diffusion of science and industry.

The goals of these writers were definitively summed up by D'Azegilo to include:

27 Fattorello, op.cit., p. 187. 
(1) the promotion of industry and agriculture by free associated effort and by the application of technical knowledge; (2) the extension of railroads on a national plan; (3) free trade; (4) a free press; (5) popular education directed by lags men; (6) lay philanthropy unj.ting rich and poor.

In the small duchies of Parma and Incca, censorship was milder and more sensible. These territories usually linked up with Tuscany and pretty much reflected Iuscan ideas and procedures. The goverrments of the two duchies were not intolerant and cruel as such-malthough the Grand Duchess Maria Louisa of Parma, Napoleon's widow, was dissolute, and the Grand Iuchess Maria Louisa of Iucca was known to be at times personally curel and inhumane. Nevertheless, both governments imposed a censorship of a sort on all literature, and could, by fits and starts, now be stringent, now less so. "Non-Juccan literature disseminated with-. in the duchy was under constant surveillance."29 Both territories were small in size: Iucca was approximately 320 square miles, and Parma was just a little over twice that size.

Modena was another one of the small duchies of the Peninsula, but unlike Farma and Iucca, its censorship was in the hands of the Sanfedist fanatics who banned Dante's works and allowed none but the most bland of literature to enter the state. Modena, in 1833, had but "...three publications,

${ }^{28}$ Massimo d'Azeglio, Proposta d'un programma per l'opinione nationale italiano (FIorence: Le Monnier, 1847), quoted in Greenfield op.cit., p. 147 .

${ }^{29}$ Antonio Cippico, The Romantic Age in Italian Iiterature (Iondon: BIackweII.\& Co., Itã., 1918), p. 31. 
religious in nature and without any contemporary information. 30 Its ruler, Francis IV, was highly suspicious of all modern inventions and technology, and almost any change was anathema to him. Francis especially looked askance at all foreign literature. It is extremely doubtiul if the Lombard journals, for instance, rarely if ever penetrated the Modenese Chinese wall of police restrictions, and if they did, whether they could have ever surmounted the parochialism of the unlettered which encompassed the overwhelming ma.jority of the population.

In the central beIt of Italy, streching from Rome north and eastward to Ferrara and Ravenna, were the areas that came under the aegis of the Papal states "... where a gov ernment of priests administered a system, fussy, incompetent and venal." 3.1 The Inquisition, unknown and terrible, kept its eyes on censorship. The power of the police had no clear limits; they could ordex a curfew, open letters, close shops and cafes, lay fines and prohibit publication and dissemination.

The historian, Macaulay, traveling in Italy in 1838, thought the states of the Pope the worst governed in the civilized world. 32

30 Charles Whitbley, Political Portraits (London: Macmilian \& Co., 1917), p. 188 .

31 Michael St. John Packe, The Bombs of Orsini (Iondon: Secker and Varburg, 1957), p. 14.

32 George Macaulay Trevelyan, The Life of Macaulay (Iondon: IJongmans Green Co., Itta., 1932), I, p. 461. 
Almost all modern books and newspapers were placed on the Index, and special opprobrium was reserved for the science of political economy. Ecoriomics, of course, was the language of several of the Lombard journals, and this fact alone, apart from any other consideration, precluded distribution of the Annali, for example, in the Papal domain.

In addition, every Papal province had its different standard of weights and measures (a.s was the case with the other states of the Peninsula as well), and what littile ecoriomic knowledge existed was medieval in charactex or utterly useless. This particularly conspicuous lack of economic sophistication was another barrier against the infiltration of outside intelligence.

Also, because "...mast modern boois of high repute and most newspapers were placed on the forbidden list..."133 it was, of course, impossible for any native literature of worth to flourish.

In the south of the Peninsula, covering some threeeighths of its furface, lay the Kingdom of Naples and Sicily. The ancient but continuing feud between the Neapolitans and the Sicilians made it "...the most distinctive and isolated of Italian states." 34 "The two states were joined only by the commonality of government; their dissimilar history, traditions and aspirations helped form their different char-

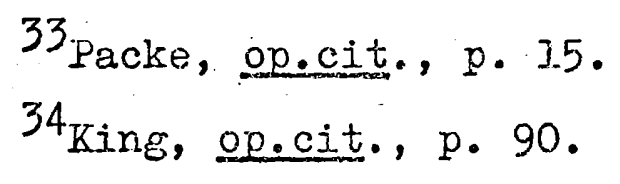


acter and social life. No political newspapers, of course, were al.Jowed. "An almost prohibitive tax kept out foreign books and other publications..."35 and surely no purely political writings of any sort were allowed no mattex what the origin. What pitiful writing was done locally almost entirely ignored the rest of the Peninsula.

In the Kingdom of Naples and Sicily after 1821 and continuing until well beyond mid-century, repressive measures were regularly instituted with respect to the press: "...indeed, repression even went so far as to burn a catechism be-m cause it numbered among the duties of man, the love of country." 36

In all the states, generally, the expense, the protracted delay, and the uncertainty of securing the censor's permission to print-not to mention the censor constantly looking over one's shoulder-aiscouraged authorship of every kind. Publications going from state to state did so only with great difficulty and danger, and most of the time for one reason or another dissemination was prohibited.

...the total number of now books and editions published in Italy in 1833 was 2811 , 3 and the majority
of these were probably re-prints. Naples was the dark heartland of the Peninsula, cutting itself off, to a great extent, from the rest of the area.

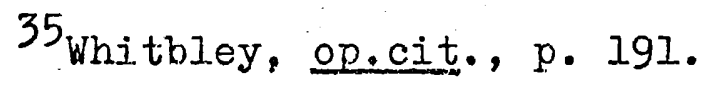

${ }^{36}$ Iuigi Salvatorelli, Concise History of Italy (New York: Oxford University Press, 1938), p. 525 .

37 King, op.cit., p. 103. 


\section{EDUCATION}

The Italian peninsula, taken as a whole, 1830-1848, had very little by way of formal education.

In 1802, under Napoleon, the French law on education was applied. Every town was ordered to "...establi.sh a school for boys, to teach them reading and writing of Italian and the elements of French and Iatin;"38 secondary schools were modernized and higher education was completely reorganized. The universities, especially Naples and Tuxin, were strengthened by revitalizing curricula with a definite emphasis on scientific studies. "A normal school was founded at Pisa, and generally, new standards of education set up."39 With the fall of Napoleon, his work was almost completeIy undone. The laws governing education were repealed-though provinces such as Tuscariy and Parma continued largely in a tradition of educational enlightenment--and the schools that the French had established were closed as revolutionary and dangerous.

The Normal. School at Pisa ceased to exist; the University of Naples dismantled; the one at Turin closed, and the Jesuits wereallowed to regain and reorganize their institutions. 4

In all the Italian states there was great suspicion on

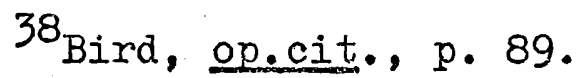

39 Ellwood P. Cubberley, A History of Education (Boston: Houghton Mifflin Co., 1948), p. 607.

40 Robert B. Holtman, The Napoleonic Revolution (New York: J. B. Iippincott Co., 1967), p. 180. 
the part of the government towards education and reading in general, so that it was almost impossible to make any headway against illiteracy, and, of course, to communicate the message and goals of the Lombard journalists to any but a very small coterie of the initiate.

Patriotism, like national loyalty, is largely a matter of educational level; deeply fel.t arnong educated people (whose nationalism often transcends other political. values), it declines as one passes to the less educated and the ilitiexate. On the other hand, the weaker the patriotism, the stronger are the indifferences to nationa $]_{1}$ origins and the sense of human brotherhood. 41

In Piedmont, the House and Court of Savoy generally set the tone for the state, and in matters of education they were retrograde. "Learning and culture in general were looked upon as needless waste of time, even unmanly and perhaps disloyal. "42

In a momentary burst of statesmanship, Charles Felix in 1822 ordered schools to be provided for boys in every commune of Piedmont; however, the government failed to provide the necessary financial grants until. 1846, and the poorer communes paid no heed to the directive. "In 1845 hardly more than half of them had schools." 43 Actually, the overwhelming majority of artisans and peasants and ever a very 4I Massimo Salvadori, Cavour and the Unification of I-
tal.z (Princeton: D. VanNostrand Co., Inc., 196I), p. 7.
42 Packe, op.cjt., p. 9.
43 Magliano Pareto, Descrizione di Genova e del Geno-
vesato (Genoa: 1846), II, p. 428-430, quoted in King, op. cit., p. 47 . 
few of the aristocracy were illiterate; however, some of the nobility read and wrote in French as well as in Italian.

The financial resp onsibility for public elementary education for girls was not placed on the Provincial Council until 1847. In the few secondary schools that existed, attendance was not being enforced; and as was the case at thjs time in many European countries only latin and Greek vere adequately taught, with courses in history or the sciences almos $t$ wholly non-existent.

The teaching was almost entirely carried on by priests who brought into the classroom the rigid discipline of the seminary and monastery which sometimes tended to blunt the developing processes of the intellect, or drove to despondency those who had a penchant for creativity. Half-hearted attempts were made to use lay teachers by founding normal. schools in 1817, and Cesare Balbo worked diligently towards that end, but those institutions perished in the reaction of 1821.

In order to register at the University of Turin--.Jesuit administered after 1823--a student had to produce a certificate of confession and communion, and have not the slightest taint of political or moral suspicion about bim.

"What literature courses there were at the University tended to be vapid and of little use, "44 and these were sometimes taught by quasi-literate teachers whose primary vocation

${ }^{44}$ C. W. Crawley, op.cit., p. 433. 
was religious and only secondarily academic.

In 1848, the Piedmontese school system came under attack by Giuseppe Sacchi:

It seems to us that they still confje too much in cloistral corporations for the popular education both of boys and girls. Education is a ministry entirely civil in character, which must not be given as $\approx$ monopoly to any privileged corporation. The torpjd disciplines of the monastery are no longer adapted. to the free expansion of Italian thought. The future is in our hands and all social classes have the right themselveg freely to direct the instruction of tireir children.

The Austrian provinces of Lombardy-Venetia were far ahead of the rest of the Peninsula in education. In theory, at least, elementary education was compulsory on both sexes from age six to twelve. All but the smallest communes were obliged to provide schools.

"In Lombardy in 1834, $69 \%$ of the boys and $42 \%$ of the girls of school age attended," 46 though there was little teaching of girls in Venetia. In rural districts, which comprised mos $t$ of the territory, the attendance of both sexes at best was irregular. The compulsory feature was not enforced.

The law imposed a fine of 50 centesimi a month for non-attendance, but it was being suspended as late as 1847, in the hope of winning over the people.

Cesare Correnti, in 1847, stated that the Iombard educational system

45 Giuseppe Sacchi, Annali: 1848, XCV, p. 233, quoted in Greenfield, op.cit. p. $248 n$.

${ }^{46}$ Aristide Fanti, "Education in Italy," A Cyclopedia of Education, ed. Paul Monroe (1.912), III, p. 501 . 


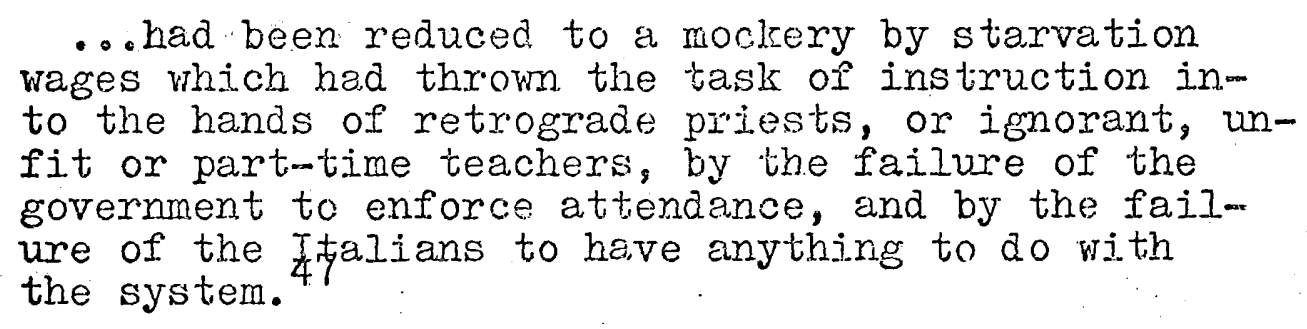

Austrian handbooks were used in the primary schools, and very little of Italian heritage or culture was imparted. Austrian law and history were taught to the exclusion of Italian in the universities.

The educational set-up of the sinali duchies of Parma and Iucca resembled more that of Lombardy than of the more backward areas of the Peninsula. In Parma, raost of the comm munes had schools for boys and girls, and about one-fifth of the population attended them or the private girls' schools.

Though Irucca was only $320 \mathrm{sq}$. mi. in size, it could boast of several schools and of relatively high attendance. "Its one university had a faculty of 25 professors." 48

In Modena, except for a very few towns, elementary education did not exist; everywhere the Jesuits had a monopoly on the secondary schools. Few people there could either read or write, and those who could do either or both, were sometimes suspect. Duke Francis literally ruined the university when in 1821 in a reactionary frenzy be introduced his new discipline which stifled independent thinking and reduced much of the instructional process in Modena to a sham.

47 I'Austria e la Lombardia (Capolago: 1847), pp. 34$36 ; 53$, quoted in Greenfield, op.cit., p. 213 .

48 Fanti, op.cit., p. 502. 
Tuscany had elementary schools for boys, and these were generally gratuitous in a.lmost every comrane; but,

$\therefore$..though in the towns the schools were fairly good, the rural ones were very indifferent, and the attendance reached to only one-tenth of those of school age. 49

The government patronized the Universities of Pisa and Siena, but little was taught beyond law and medicine.

"Ignorant people," said a Monsignor in Rome to d'Azeglio in 1840, "are easier to govern." 50 There were in rost of the Papal states educational institutions, but instruction was monopolized by the clerics and made useless by a rigid and hopeless curriculum. Prospective teachers had to secure the approbation of the local bishop before they could instruct; of course, secondary education was in the hands of the Jesuits. Elementary education, such as it was, generally failed to reach large sections of school-age children. It was estimated--though no formal survey was made--that "... only $2 \%$ of the population in the Papal States attended school, and this irregularly. Even in Rome, itself, the proportion was only one in ten." 51

At the secondary level the courses were mainly centered around Latin, grammar, scholastic metaphysics and related studies. At the universities modern litexature and political

${ }^{49}$ Sir John Bowring, Report, p. 11, quoted in King, op. cit, p. 70 .

50 Guido Biagi (ed.), La Vj.ta Italiana nel Risorgimento, 1815-1831. (Firenze: R. Bemporad and Figlio, 1897), p. 177 . p. 80 .

${ }^{51}$ Bowring, op.cit., p. 85,89 , quoted in King, op.cit. 
economy--among many other requisites-were excluded, and unti.l. 1835 Latin was the langliage used in teaching law, philosophy and medicine. In oxder to register for the university, it was necessary to produce the governor's and the bishop's certificate of what was deemed acceptable religions, moral and political conduct.

In the Naples' half of the Kingdom of Naples and Sicily, the gurf in education between theory and practice was great. "By law of 1810 every commune except the sinallest was bound to have its primaxy school, every province its secondary school." 52 However, no effort was made to bring the students to them. Even in Naples, itself, there were but four gdatuitous public schools, and only one in three of school age attended. No provision for girls was made in Neapolitan education, except for some few convents.

In the provinces the situation was even worse... The hierarchy did it utmost to negate the efforts of the Ministry of Education to open and operate schools. "There were whole communities without a literate peasant." 53 . How general was the ignorance is showa "...by the law that required one-third of the members of a tow council should read and write." 54

The Neapolitan secondary schools, when they existed, were pitifully poor in staff and curricula. In the matter.

${ }^{52}$ Cubberly, op.cit., p. 607.

53 Ibiả.

$54_{\text {King, op.cit. }}$ p. 90. 
of education, as weII as in other things, "...Ferdinand IV favored the clergy which numbered one-thirteenth of the population." 55 The University of Naples, though it had once known Thomas Aquinas as a fledgling cleric and Vico as a scholar, had become overcrowded by students, "...many coming to it more for the idle life of the capital with its often demoralizing influence, than for sexious study."56 At that time ignorance and suspicion permeated the institution, adding up to one vast wasteland of mediocrity.

The educated class in Naples -what there was of it.mon consisted of a small group of lawyers, usually unemployed and poverty stricken, and some few literate members of the aristocracy; however, they were generally devoid of that energy and sense of nascent patriotism sometimes found in the northern part of the Peninsula. Yet, paradoxically, Naples boasted of having completed the first railroad and the first iron bridge in Italy.

In Sicily, the other half of the Kingdom, there was alinost no education at all; even the children of the nobles were sometimes hardy literate.

Most Sicilian villages possessed no school... Maniscolo admitted that his fellow Sicilians were uncivilized and without either education or idea of morality $_{57}$ Many important Sicilians like things as they

55 Packe, op.cit., p. 11 .

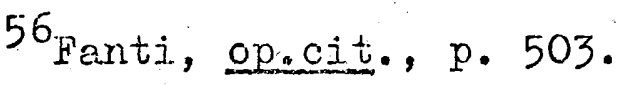

57 Dennis Mack Smith, A History of Sicily, Vol III: Modern Sicj]y (New York: Viking Press, 1968), p. 427. 
The backwardress and general illiteracy of the South, especially Sicily, was illustrated by the difficulty of applying uniform laws. The processes of government attempting to enforce law and order were at best sporadic, at worst, chaotic. Quite apart from the conservatjve-religious ideology which was to be found at all levels,

...the social system inhibited the growth in Sicily, itself, of a literate middle class which might accept refolutionary ideas of liberty and economic progress.

The only Iiterate Sicilians-some lawyers-were completely subservient. "The three universities on the island. were feeble institutions...," 59 and these were a detriment to the conservatives as well as to the extremely few Iiberal adiherents because the universities promoted a kind of narrow outlook which at times made the students an unruly flock.

Political education was primitive in Sicily, even a generation after the period considered by this paper:

Maxine du Camp in Sicily in 1860 heard people in the streets shout, 'Iong live Italy,' and then ask their neighbor what the word 'Italy' meant. Another observer heard people join in the cry of ' 'Long live the King and the Constitution,' but. what they were saying proveg to be llong live the King and his uniform."

In summary, it may be said that it was not until the Napoleonic invasion at the end of the I8th century that the modern laic trend in "Italjan" education began and the first

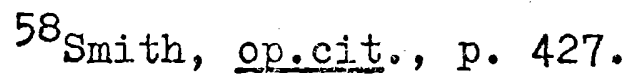

${ }^{59}$ Ibid., p. 412.

60 Denis Mack Smith, Italy: A Modern History (Ann Arbor: The University of Michigan. Press, 1959), p. 55 . 
steps taken toward an entirely lay and modern organization of instruction. After Napoleon's defeat, however, the Jesuit returned and generally remassumed control of secondary education in almost all the states, with the exception of Jombardy-Venetia, Tuscany and the duchies of Farma and Iucca. In many instances, too, the Jesuits and other religious orders were given proscriptive rights in higher education, so that "Italian" education-what there was of it--became again the dominion of the clergy who often were inept as teacher's, and as a general class remained in that condition for many years to come.

It has been estimated-though there exists no survey to back up the figure--that "...less than $2 \%$ of the total population of some 14,000,000 people in the Peninsula was literate."61 In 1901, it was calculated, based on a statistical survey, that $49.9 \%$ of the population 15 years and older, were still classed as illiterates. 62 To take an even later sampling of general Italian illiteracy: in the 1907-1908 school year, it was reported that there were 182,373 adults enrolled in evening and Sunday schools, and of that number, only 77,717 passed the examination at the end of the year. 63 Again, in a 1911 survey, the percentage of illiteracy 'was

${ }^{61}$ Cubberley, op.cit., p. 607 .

${ }^{62}$ Annuario Statistico, Istituto Centrale di Statistica (Roma: 1955 ), p. 451 .

63 Fanti, op.cit., p. 503. 
still appalling: "...40\% of the Italians were illiterate, the proportions being higher in the southern part than in the northern part of the Peninsula." 64

Ihis prevailing and persistent illiteracy and lack of educational opportunities militated against any proposition that holds that there was being developed in the 1830-48 era "... an Italian public opinion... that could never again be governed successfully by the principles and methods of the ancien regime...:"65 or that postulates that the "...great mass of educated Italians who had too much commonsense or too little courage for Nazinji's gospel, were looking for a milder creed which would reconcile patriotism and prudence." 66 Italias mine.

\section{IANGUAGE}

Certainly language--or better called dialects in the case of the states of the Peninsula--constituted formidable barriers to communication in the 1830-48 period. The Iorlbard journalists resorted to "indirect" writing in a kind of "code" language that required a certain degree of intellectual sophistication on the part of the reader to understand. The linguistic obstacles were therefore almost insurmountable in this land where being illiterate was the condition of so much of the populace.

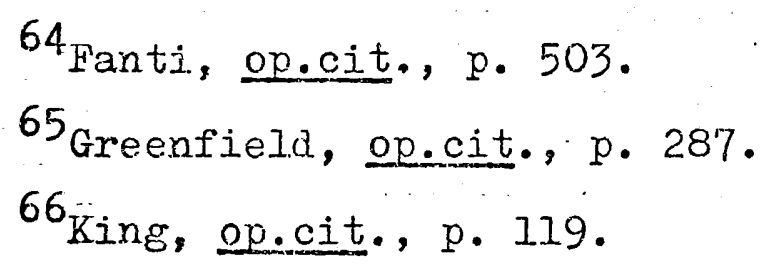


Some three hundred years earliex, the great Erasmus had something to say about the Italian Ianguage:

The Italian dialects are unfixed, imperfect and unequal to varied demands of a literature. Italian is the quintessence of barbarism--that barbarism which overthrew civilization itself in its own land. How prefer a language whose roots lie 6 in the invasion of the Goth, Vandal and Lombard?

Down to the I9th century and even into the 20th, the words of Erasmus still had some validity. In the Peninsula at this time there were literally hundreds of dialects, each separate and distinct and bearing very little relationship to that of the adjoining village. For instance--just to name some of the major dialectsm- there were: The Romagnol, more foreign-mounding than Italian; the Piedmontese, heavily laden with French words; the Lombard with its various Germanic words and inflections; the Neapolitan with its Spanish; the Tuscan..... language of Dante and soon to become the basis for the national language; the Roman with its Latin admixture; and the Sicilian with its Saracen, Norman and Spanish linguistic potpourri.

Very important in delaying Italy's national movement was the absence of a generally agreed national. language. Strong regional sentiments had kept many dialects alive which were unintelligible to stran-gers from other provinces, and 6 these were the normal speech of nearly all Italians.

Some of the great "Italian" literature of the I8th cenm

67W. H. Woodward, Desiderus Erasmus: Concerning the Aims and Methods of Education (New York: Columbia University Press, 1904), p. 68.

68 Dennis Mack Sinith (ed.), The Making of Italy, 17961870 (New York:... Harpex \& Row, Publishers, 1968), p. 71. 
tury was written in dialect. Meli, for instance, wrote his poems in Sicilian; Goldoni chose to write plays in Venetian, and Alfieri, the first playwright of the Risorgimento to stix nationalistic feelings, could never really divest himself of his French culture, even though he spent some time in Tus. cany for the expressed purpose of learning the language of that area, already recognized by some as a "literary" dialect. Even the great Garibaldi spoke and wrote in a dialect-m the Nicois which was of Francomprovencal derivation, along with Genoese, the lingua franca of maritime peoples of the Tyrrhennian Sea, Moreover, the mutilated French-and-Piedmontese mixture that Cavour used even when addressing Parliament was not to be found in any "Italian" dictionary.

Even in Piedmont, difference of language is our great difficulty. Our three native languages are: French, Piedmontese and Genoese. Of these, French alone is generally intelligible... Cavour is natur. ally a ggod speaker, but in Italian he is embarrassed.

So, the dialects were an jmportant obstacle that tended. to keep the people of the Peninsula divided and hostile. Since the days of Dante, poets and statesmen had talked and written of "Italy" and "Italians," but the people had felt themselves to be Roman, Sicilian or Tuscan.

When Alessandro Manzoni, along with some other educated "Italians," had decided that of all the dialects the Tuscan was the richest and the most beautiful, he had only just be-

69 William Nassau, Sr., Journals Kept in France and Italy (London: Blackwell. \& Co., 1871), I, pp. 29.1-2, quoted in Smith, The Making..., p. 71 . 
gun on the problem of writing a popular novel in it. There was, for example, no authoritative dictionary, except for the incomplete Vocabulario della Crusca, which consisted almost entirely of words taken from the works of Iuscan writers of the 14 th to the 16 th centuries. No matter how useful this dictionary was for poets writing of courtly love, for jour nalists of the 19th century writing of economic and techron logical progress, it was pitifully inadequate. "A written Italian did exist, but it was known only by a smals minority and spoken by even fewer."70.

One result of this pastiche was to bring into being yet another dialect: literary talk, which was perhaps

...pure, capable of subtilities, power and refine-ment; it certainly was involved, and no one, not ever. writers and educated aristocrats consistently talked it. The great mass of Italians, the peasants and the middle class, did not talk it at all. Writers of all sorts, literary and political, despaired over this; langyage was a barrier not a bridge to communication. [Italics mind]

Right up to the present time, the common everyday speech in almos $t$ all of Italy is either a local Italian dialect different from the standard. language, or the standard influenced by local usage. The less formal the occasion and the less educated the speaker, the greater are the deviations from standard Italian; many persons in Italy cannot

70 E. Pulgran, "The Tongue of Italy," Encyclopedia Britannica ed. A. J. DeVito, III (1968), p. 7II.

${ }^{71}$ George Martin, The Red Shirt and the Cross of Savoy (New York: Dodd Mead and Co., 1969), p. 222. 
speak the standard Italian at all. However, with the introduction of television in 1954, the use of standard Italian has been growing among the masses. But, as of 1954, it is estimated that "...roughly $80 \%$ of the population preferred to speak in local dialects-and their efforts at a standard Italian phrase frequently sounded awkward."12

Not to be forgotten in the discussion of dialects is the folk-song which was probabiy one of the stronger elements working to create a national jaea, and which was universally popular at this time, e.g. "La Violetta" lauding: the Bersaglieri (A piedmontese outfit, 1836) and sung alI over northern Italy before 1848. Another song" was "Santa Iucia;" these songs were al.so sung around the fires at night in the cascine (houses) and they would uswally lament the social conditions of the times, e.g., the need to serve in armies far from the homeland, or to travel to distant land.s against one's wishes, etc. Somehow, through the magic of melody, these songs were taken up and understood by village after village, notwithstanding the dialectal barrier, and were probably every bit as effective as any phrase or melody picked up from a Verdi opera and passed along by the patriots.

Too, around the night-time fires of the cascine were read the popular almanacs written especially for the commonp. 57. "Talking Iike a Native," Newsweek, March 9, 1970, 
man in words of one syllable with pencil sketches, $\underline{e} \cdot \underline{g}$, , Il Nipote della Veste Verde. The sketches were plain enough for many to understand, and the allusions were there; sometimes there was someone around who could read the almanac to the others, but the impact of this is difficult to measure inasmuch as the peasant was bound to the land in a sunrise-to-sunset regimen with little time for political thinking or activity.

In summary, as fax as the Iombard journalists were conm cerned with regard to their efforts to communicate to other areas of the Peninsula the message of economic and technological advancement, 1830-1848, the dialectal barrier was almos $t$ impenetrable, for there was little by way of common linguistic denominator, and therefore little means by which the written word could function as a catalyst in the effective development of the national spirit. The folk-song and the almanac were probable exceptions to this.

\section{IETHARGY}

Few people in the Peninsula, 1830-1848 (and beyond that time) believed that there might exist eventually an Italian nation. There were at that time eight states, each with its distinctive laws and traditions, dialects (as we have seen) and different standards of weights and measures-and even currency, Napoleon's partial experiment in unification was never revived at this time because very few had the desire, and the resources for such a feat were virtually nil. "Much 
of the peasantry-which made up the overwhelming majority on the Peninsula-..did not care about unification."73 In the Austrian provinces of Iombardy-Venetia, for instance, the peasants and perhaps to a somewhat lesser degree, the artisans in the towns, "... were not easily moved to hatred of Vienna."74 Comparatively speaking, their prosperity was good; they reaped direct benefits from the progressive Austrian irrigation schemes and from being included, with their fextile holdings in the rich Po Valley, within the impexial economy.

Most Italians were traditionalists; a large majority of the two privjledged classes, a smallex majority of the middle classes, and the overwhelming majority of the peasantry. Firmly attached to the past and solidly opposed to innovation of any kind, deeply--almast religiously--loyal to the institution of the absolute state and to the ideas behind them, they were convinced that authoritarianism was the best guarantee of order and happiness.

Clericalism--that all pervading intellectual and political influence of the clergy--was the main component, even the foundation, of traditionalism. Tram ditionalism meant the conviction that the good belongs to the past and that privilege--political, economic, ecclesiastical--belongs to the God-estabIished order of nature and therefore must be upheld; it meant the acceptance of a rigid hierarchical structure of society with total power con-

${ }^{73}$ Louis Mazoyer et al, "Italian Unification, "Larousse Encyclopedia of Niodern History. ed. Narcel Dunan (1964), p. 313.

${ }^{74}$ Edward Crankshaw, The Fall of the House of Habsbure (New York: Viking Press, 1966), p. 138. 
centrated at the top. 75

The French Revolution and the rationalists of the Enlightenment produced slogans, such as "liberty," "equality," "freedom of conscience and of thought," but these were diametrically opposed to what the traditionalis ts believed to be the good and necessary condition of man; lastly, one could conclude that traditionalists believed that the ignorance of the inert and docile masses was much preferable to the knowledge of libecated and prosperous citizens. "The intellectual. Iife of the masses moves within a very limited range... innovators find no great sympathy among the masses." 76 The Peninsula had not been united as one for some 14 centuries, and this fact, no doubt, accounted for much of the political indifference--even lethargy--of the populace. "The curse of Italy was inertia and division." 77

\section{Provincial Antipathies}

Hostility among the provinces, communes, villages-meven families-abounded within the Peninsula to a degree rarely noted in the history of nations. Ancient hatreds fanned into pererinial feuds based sometimes on the accidents of geography or history or the circumstances of racial admixtures-.or almost any genre of reasons-permeated in varying degrees

\section{${ }^{75}$ Salvadori, op.cit., p. 28.}

${ }^{76}$ Camillo Cavour, "Des chemins de fer en Italie, par le comte Petitti," Revue Nouvelle (Paris: May 1, 1846), reprinted in Smith, The Making....2 p. 106-7.

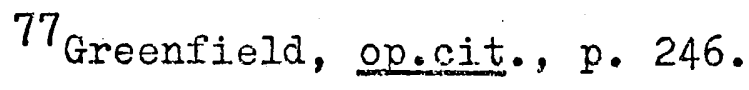


all regions and made impossible any real communication and understanding which might ultimately lead to associations for mutual benefit.

The very blood that coursed through the veins of the Sicilian was different from the Neapolitan, for the latter had Spanish blood as well as Italian, the formex had large admixture of Norman, Saracen and Berber blood. The difference in heritage, the quasi-tropical climate, and the sense of distance and some independence from Naples, produced a character that had nothing in common with that of the mainland.

Known visitors from nearby villages were often referm red to as "strangers" or "foreigners," and the southern part of Italy, especially from Naples to and including Sicily, was ta.zked of as "another country,". by the northerners and vice versa. This untoward situation was recognjized and understood by the liberal thinkers and writers of the North: "...that the Kingdom of Italy is impossible with the vanity of opinions, of intentions and of states...divisions with their fruitless and ruinous animosities." 79 one famous journalist in 1831 saw clearly the seriousness of the Peninsular conditions:

From what cause had sprung those evils that through the centuries had tormented the Italian people and placed them under the heel of a foreign oppressor? Is it not to be found in internecine struggles, the rivally between the petty states, the fraticidal warfare that render Italian histor'y so bloodstained and

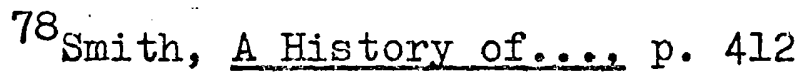

79 Cesare Balbo, Delle speranze d'Italia (Capolago: 1844), p. 437, quoted in Williarn J. Stillman, Union of Italy 1815-1895 (Cambridge: Cambridge University Press, 1899) p. 125 . 
pitiful. 80

What headway could the liberal journals of Lombardy make in such a dilemma, particularly when their writers were forced to write circuitously to obviate the censor, and in the language of statistics and in the nomenclature of technology?

The scandal of division, hostility, pettiness, disorganization and confusion was best summed up by the "Prophet" of the Risorgimento:

We have no flag, no political name, no rank among nations. We have no common center...we are dismem. bered into eight states...all independent of one another, without alliance, without unity of aim. Eight lines of custom houses... sever our material interests ...enormous duties check the imports and exports of articles...territorial and industrial products abound in one province that are deficient in another; and we may not freely sell the superfluities or exchange among ourselves the necessities. Eight different systems of currency, of weights and measures, of civil, commercial and penal legislation, of administration, of organization, of police restriction, divide us and render us as much as possible strangers to each other. There exists not in any of these states either liberty of the press, or of united action, or of speech, or of collective petition, or of introduction of foreign books, or of education. One of these states, comprising nearly a fourth of the Italian population, belongs to the foreigner-mto Austria; the others, some from family ties, some from a conscious feebleness, tamem ly submit to her influence.

From Napoleon, himself, who held the Italian people "... incapable of self-government, and his many contemptuous

80 Angelo Brofferio, Messagero Torinese, 1847, quoted in Maurice Paleologue Cavonr. (New York: Harper \& Bros., 1927), p. 59 .

$81_{G}$. Mazzini, "Italy, Austria and the Papacy," Young Italy (Iondon: 184.5), quoted in $\mathrm{E}$. Iipsor Europe in the I9th Century (New York: Maclílian Co., 1962), p. 171. 
utterances on the subject are crude and blind to a point where the bistorian feels embarrassed to quote them, "82 to Austria's Prince Metternich who often referred to the emnity that pitted provinces against provinces, towns against towns, families against families--even men against men-m, finally, to the liberal writers, themselves, it was obvious then, as it is now, that the populace of the Peninsula--even by $1848-m$ was not, and could not, be disposed to be moulded into an "informed public" having opinions and aspirations relative to the advantages of economic progxess, technological advance.. ment in a general trend toward forming the national spirit. Greenfield, himself, quotes a stinging accusation that gives the lie to any appreciable, effective inter-provincial journalistic communication:

Granche! We are sons of the same land, all of us enjoy equally the same sky... We have the same religion, venerate the same glories, and yet some are ignorant of what the others are doing... It will seem strange at first thought to hear it, but you know well that morally speaking we are more distant from Turin than from Vienna; here the literary conditions and activities of Paris are better known than those of Rome or Tuscany, and comparatively speaking books reach us more rapidly and tozgreater abundance from London than from Naples.

82. Marshall B. Davidson (ed.), The Age of Napoleon (New York: American Heritage PubIishing $\left.\bar{C}_{0 .}, 1963\right), \mathrm{p}$. 118

${ }^{83}$ Gottardo Calvi, "Notizie letterarie della Toscana," Rivista europea, 1840, III, Pt. 3, p. 311, quoted in Greenfield, op.cit., p. $274 \ldots$ 
The Greenfield thesis on the efficacy of Italian "na-: tional journalism," 1830-1848, toward the formation of the national spirit, may be summarized by the following statements:

By 2848, largely through the journalists' efforts. an Italian public opinion had been formed thet could never again be governed successfully by the prinn ciples and methods of the ancien regime, less because the material interests of the italian community had been revolutionized than because the public had been indoctrinated with a new conception of: their interests. [Italics mine]

And again:

One of the important offices that liberal journals performed was to familiarjze the whole Italian public with the names, the writings agg the opinions of its future political leaders. [Italics mine.]

\section{Finally:}

Hobbled by the censorship and operating on a pubIic limited by inertia and ignorance, Italian journalism had developed a class of publicists and made them kxiown to each other and to Italy: jt had be- 86 come a major force in shaping the national program. [Italics mine.]

Greenfield also points out "journalistic achievements" in specific cases, e.g., the engendering of scientific con-

${ }^{84}$ Greenfield, op.eit., p. 287.

85 Ibid., p. 278 .

86 Irid.s p. 198. 
gresses beginning in 1839, the promotion of asili d'infanzia, in the late 30's (actually, first introduced in Cremona in 1829 before some of the Lombard journals even existed), Iectures for the adult education program beginning in 1844, etc., but in each case no direct or indirect relationship is proved, except to establish a time sequence following publication of pertinent information in some Lombard journal. However, as pointed out previously, sequence of events does not necessarily point to, or even imply, a cause-and-meffect relationship.

other authors, too, give their support, variously, to the concept of an Italian informed public opinion favorably disposed towards the formation of the national spirit at that time. One author referring to the period following the abortive uprisings in Fiedmont in 1832 , writes of the

...deadness of the previous decade had lifted and the great mass of educated Italians who had too much commonsense or too little courage for Mazzini's gospel, were looking for a milder crefed which would reconcile patriotism and prudence. [Italics mire?

And the above is bolstered by yet another author:

At the end of the 18th century and into the 19th century the time was ripe for the appearance of new newspapers in Italy-a literate public was waiting for them; the French Revolution and the career of Napoleon had stimulated thought and the ag:8 of mechanical invention was making it possible. IItalics mine?

After referring to the Annali, Rivista europea and Politec-

${ }^{87} 7_{\text {King, op.cit., p. } 3.19 .}$

88 Iucy M. Salmon, The Newspaper and the Historian

(New York: Oxford University Press, 1923), p. 33 . 
nico and to the edicor, G. D. Romagnosj, as one of the greatest Italian intellects, another author maintains that these journals "...drew contributors from other states...thus getting in contact with the progressive elements all over northern Italy." 89 Italics mine.

On the other hand, another author refers to the Lombard periodicals as "...dull trade journals." 90

${ }^{89}$ Hearder, op.cit., p. 132-133

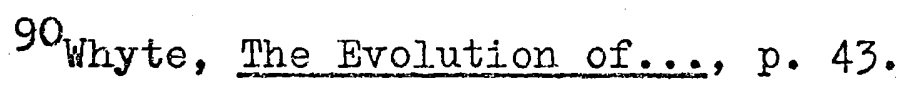




\section{DISCREPANCJES}

In view of the obstacles ${ }^{91}$ which militated against any appreciable degree of journalistic effectiveness in the formation of the Italian national spirit, some of the propositions in the conclusions of the Greenfield thesis suggesting that the liberal journals-with specific reference to the principal Lornbard journals--exercised widespread influence over the "whole Italian public," and that consequentiy, , these journals became a "major force in shaping the national program," are open to question. A closer look at the judgments which "lead" to the Greenfield conclusions reveals that some are based on improper inference and even contrary statementis.

In Italy, 1830-1848, except for the rush after 1847 to found several bona fide liberal newspapers (e.g., Cavour's II Risorgimento, 1847, in Piedmont), most of which were quickly suppressed in the reaction of 1848-1849, there were no newspapers as such in Italy, except for official ("Privileged") gazzettes in each state. In every case, the gazzette was biased to reflect the respective government in a favorable light-what might today be called "managed news." 92 In 1833 in Italy there was a "...total of ninety-two journals...," 93 including the ecclesiastical ones, and these

${ }^{91}$ Supre, pp. 12-40.

92 Supra, p. 4.

93 Greenfield, op.cit., p. 150. 
were almost wholly conservative and concerned with religious matters. Out of this number, Greenfield, while briefly mentioning other organs ranging from reviews to almanacs, singles out over a span of several chapters, only three (plus the short-lived but mercurial II Conciliatore), as effective promotexs of liberal nationalism at this time.

Il Conciliatore (1818-1819), the Annali universali di statistica (1824-1848), the Politecnico (1839-1845) and Rivista europea (1838-1848), are the conspicuous and recognized champions of liberal nationalism a.m mong the journals of Iombgrady in the period between the Restoration and 1848.

Three periodicals, published in Iombaray at ajfferent times, hardly seem adequate to filfill the office of effectively helping to promote the national spirit, no matter how influential each one of them might have been. Moreover, a.l工 three organs had to put across their message by "indirection," allusion, "code," and when writing of economic progress and technological improvements had to resort to the ponderous language of statistics and the terminology of the machine. In addition, they had to reach a public separated into eight states, each with relatively stringent controls on dissemination of "foreign" journals. It is difficult to understand how the journals, when referring to economic or mechanical subjects, could find a common ground of discussion having popular appeal in such diversity and under such stricture. Also, much of the subject matter itself had little of interest to those living on the Peninsula. The Annali, 
for instance, came out in sober, octaro leaflets, printed in small, close-set type, with little paragraphing and

...touched on subjects ranging from education and geography to ancient astronomy, ritual architecture, and the history, the books, and the present conditions of the East, a subject in which Romagnosi was particularly interested.95 [Italics mine.]

In the above listing, there was probably one, maybe two, subjects of interest to the reading public of Lombardy or elsewhere at that time--education and geography. But ancient astronomy, ritual architecture, and the history, the books, and the present conditions of the East must have been of littile interest or value even to the very small coterie of Jiberal intellectuals.

Greenfield states that "...the Annali...sought in statistics a weapon less worn and blunted than historical lamentations and poetical anathemas." 96 Yet, earlier in the work, he states contrarily that "...the Italian inind notwithstanding its brillian contributions to modern science was traditionally preoccupied with the glory of literature and art." 97 Then how could the reading public interest itself in statistics and see in them a nascent spirit of nationalism when it had for centuries known some of the finest literature of the world: it was aesthetically--not statisticallyinclined.

An idea of the jouranlists' obscure language and of

$95_{\text {Greenfield, op.cit., p. } 277}$

96 Ibid., p. 278.

97 Ibid., p. 246. 
how they intended to communicate their message may be gleaned. from the following remarks by a famous Lombard joumalist speaking years later of the heritage bequeathed to his disciples by G. D. Romagnosi, famous editor of the Annali and mentor of jourmalists:

I resigned myself, an impatient conscript, to the discussion of averages, tables and numbers, which gave us a chance to talk in jargon and in cipher, and to withdraw ourselves from the mutilations of the censorship, accustomed as it was to sniff only at phrases, epithets. The thing was done. Numbers spoke their language only to those who lnew how to read their hints: true language of mutes $\because \cdots$ a response more intimate gig intellectual than the casual jingle of rhymes. "Italics mine.]

Again, in view of the obstacles noted earliex, and in consideration of the italicized segments of the above quota... tion, jt is logical to question whethex the Annali, for instance, with its format and content of "jargon," "cipher," "rumbers," etc., could have been in a position to appreciably aid in the effort to "familiarize the whole Italian public" with the names, the writings and the opinions of its future political leaders.

Apart from other considerations, such a process of mass familiarization would have required not only a large literate reading public, possessed of linguistic facility with myriad dialects, with currency, and have a dynamic interest in the economics and technology of the day, but also a public with a necessarily high degree of intellectual acumen and sophistication to enable it to "read between the Iines," etc. Ihis

$98_{G}$. Massarani, Correnti, pp. 62-63, note 1 , quoted in Greenfield, op.cit., $\mathrm{p}$. 166 . 
assuredly, the illiterate masses, and no doubt some of the literate minority of the populace, were not in a position to accomplish.

Again: "Romagnosi wrapped his thought in such cryptic language..."99 To this may be answered that there is no escaping the fact that "...intelligibility requires intelli... gence," 100 on just the ordinary, direct level of understanding, to say nothing of the complicated message of statistics, the esoteric history and customs of the East, the unfamiliar Iiterature of France and England, commuicated by indirection, allusion, etc., win an attempt to relate all of these to the conditions on the Peninsula.

In the case of the second principal periodical-...the Rivista europea-mand its role in the formation of the national spirit, Greenfield avers that

...the Rivista europea, with its national battery of correspondents, with a staff that embraced the best minds of the new profession of journalism that had been developing for 20 years-heir to the concili-: atore and the Antologia of Florence, as well as the Annali and the Politecnico--achieved a synthesis of the whole new economic, scjentific and cultural Iife of Italy and spoke. criticized and exhorted in the name of the nation, with a wejght of authority that none of the others achjeved. [Italics mine.]

But before, stating the above, Greenfield affirms that The Rivista europea displays no such unity of con-

${ }^{99}$ Greenfield, op.cit., p. 256.

100 Eric Newton, The Romantic Rebelizion (New York: St. Martin's Press, 1962), p. 65.

${ }^{I 0 I}$ Greenfield, op.cit., p. 277. 
ception as that which Cattaneo dominated the Politecnico. Characteristically, it started without an Introduction or Declaration of Principles, and. its pages betray vicjssitudes of policy which are reflected in changes of rubrics and in variations in the guality of the contents. These are traceable in part to the fact that staff did not remain constant. "IItalics mines]

The contradictions in the above two paragraphs are obvious and need no comment.

The collaborators (or as they would be called today-editors) of the principal joumals appeared to have had more than their share of difficulties in working together. Jourm na.ls were founded and soon, for one reason or another, one or more of the original founders or collaborators would break away, usually to form his cwn staff and found another journal, making for a rather unstable working arrangement to say the Ieast. The Rivista europea is a case in point. Carlo Cattaneo was part of the editorial staff of the $\mathrm{Ri}$ Vista when it was founded by Giacinto Battaglia in 1838; by the following year Cattaneo was out of the Rivista and then founded the Politecnico. Moreover, no sooner had Battaglia founded the Rivista that he, himself, was complaining of in sufficient support from his collaborators and lamenting the many troubles with which an Italian editor had to contend:

By 3.844 he was out of the management and the review came under the direction of the young Gottardo Calvi, and then in 3.845, of Car 183 Tenca with whose name it is commonly associated.

$$
\begin{aligned}
& 102_{\text {Greenfield, op.cit., p. } 186 .} \\
& 103_{\text {Ibid. , p. } 187 .}
\end{aligned}
$$


Another obstacle for the joumals was the fact that they perennially labored under a financial handicap, for there was always the limitation of their paid...up subscriptions. Greenfield points out that Giacinto Battaglia of the Rivista

bitterly complained of the difficulties arising out of this. 'The foreign publisher,' he said, whether English, French or German, started with a 'pile of gold on his lap' with which he could get prompt service from contributors and secure unity of aim in their collaboration, while in Italy, he had to beg them; he could not pay enough, they therefore had other interests and obligations and he had to be satisfied with what they cguld give him at their convenience and pleasure. [Italies mine.

The journals under these conditions, it would seem, could hardly speak "with a weight of authority" if their journa..istic sources depended on such tenuous circumstances. Too, they were far from successful business undertakings; they had to depend on other sources of supply for their income: "...patronage from persons of wealth," ${ }^{105}$ a situation that made at best for an insecure, dependent condition.

In the case of the third principal journal, Carlo Cattaneo's PoIitecnico, 1839, Greerfield states that

...the Politecnico published longer and weightier articles than the Annali. Its itire was less scattered. But, on the surface at least, it is not easy to define the difference of purpose from that of the older journal, except for the obvious dominance of a single mind--that of Carlo Cattaneo--

${ }^{104}$ Giacinto Battaglia, "Ai lettori ed ai collaboratori," Rivista, 1840, III, pt. I, vi-vii, quoted in Greenield, op. cit., p. 192 .

${ }^{105}$ Cazzamini-Mussi, op.cit., p. 189. 
over its pages. 106

And in a further effort to show unity of purpose of all three journals, Greenfield states that

... if the outlook of the free journals in Iombardy was cosmopolitan, or at least European, it was no less decidedly Italjan. The journals were Lombard only in the sense that they were directed by Lombards. [Dtalics mine]

But again, according to Greenfield, not all three journals were "cosmopolitan" or "Italian" in scope, and the Politecnico is a case in point.

The Politecnico reflected the powerful glow of Cattaneo's affection for his own region. While his journal proceeded like the others from the assumption that Italy was a cultural and econ-m omic unit, its editorial policy was rooted in the interests of Lombardy. For all the ampli... tude of its horizon, it was primarily occupied with the task of relating life in Lomegra to the economics and science of Europe. [Italics mine?

Again, it can be demonstrated from the thesis that the journals were not always "Italian in scope," and the $\underline{R}$ vista's policy may be taken as another case in point.

The Rivista europea...manifested first of a.l ...its preference of original articles by Italians to borrowings from soreign journals. At the end of 1840 , Battaglia had to admit partial defeat on this score and announced in 1841 that he would resort more often to translations of articles of foreign reviews. [Italics mine]

Moreover, "the journals borrowed heavily from the French jour-

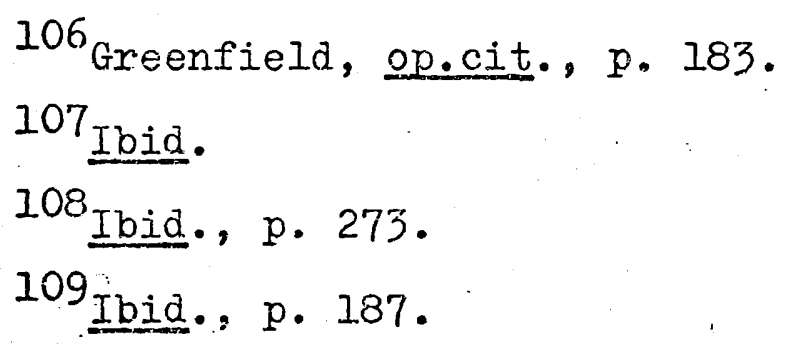


nals. " 110

The thesis would further have the proposition believed that there were correspondents all over Italy contributing to the Lombard journals, thereby making them truly "national" in scope by such other statements as, "The Rivista europea with its numerous regular correspondence from all over Italy was the most successful of all." 11 However, later in his work, the author admits that the Papal domain, for instance, untiI 1846 yielded ljttle by way of correspondence. Even after Fius IX's brief flirtation with "Iiberalism," the area was e.gain "...mostly closed to correspondence."

As for Naples, the journalists made a brave effort to report its progress, of which they gave glowing account, but they complained that it was almost $3^{\text {im- }}$ possible to get the information they desired.

It can be concluded, then, that if jt was well-nigh impossible to get information from these two large areas-which together made up more than $60 \%$ of the geographical area of the Peninsula--the journals could hardly be said to function as effective instruments in the formation of the national spirit. The constricted outlook of the Politecnico, and the restricted correspondence which emanated from hardiy half of the Penirisula, permeated the Lombard journals with regionalism to a great extent, rather than nationalism, and

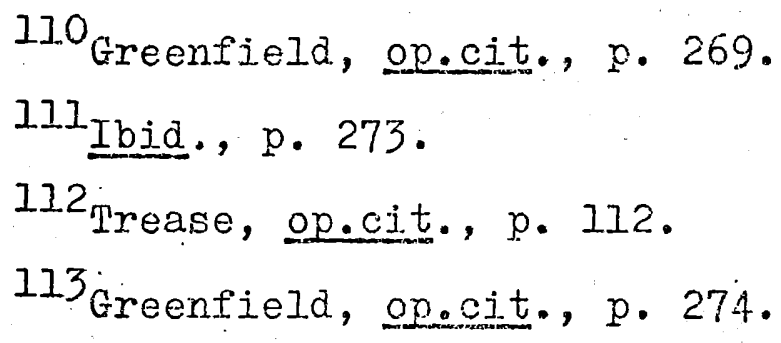


the "national battery of correspondents" was not national at all.

Eschewing for the moment the obstinate barriers to the formation of the national spirit mentioned earlier, reference must next be made to the circulation figures of the Lombard journals as reported by the thesis. These figures are far from indicating any widespread contact with the "whole public."

Circulation figures of the Annali ranged between 350 and 500. The Bibloteca Italjana was sold under official pressure, issued an edition of 800 in 1822 , but this peak was not reached again... the Politecnico got out one edition of 1000 . The Rivista ran an average of 750 copies. [Italics mine $]$

After stating the above indication of very limited distribution and not informing whether figures are based on semi-weekly editions (as in the case of II Conciliatore) or weekly, Greenfield goes on to explain that because

...records became fragmentary after 1839, when Rivista europea and the Politecnico were in their prime, any sort of statistical computation based on these manuscripts is impossib]e. IItalics mine

In view of the above--again--that part of the thesis holding that the journals became a "major force" in shaping a national program is most assuredly attenuated.

In Florence

...the Antologia in its prime had a subscription of 750 copies... only with firmness and prudence was the

114 Greenfield, op.cit., p. 275.

115 Ibid. , p. 19In. 
Antologia able to continue for such a long period of time its efficacious action, whereas eloewhere publications were miserable, with the only excep= tion being the Bibloteca Italiana. [Italics mine]

Moreover, it is stated that "...the number of readers exceeded the number of subscribers."117 A journalist is cited as declaring in 1833:

In our country...it is customary for a subscriber to share a journal with his friends and acquaintances; and... in the smaller cities where thereflare reading rooms very few subscribe individualiy.

Fur thermore,

The writer felt that it was safe to count on ten readers to every subscriber. He calculated that the average edition of an Italian periodical numbered 300 , and reached the conclusion that $t_{1}$ ere were 180,000 readers of journals in Italy. [Italics mine]

From the lack of proof-from at best "fragmentary evi-dence"--one can only logically conclude that the foregoing figure of 180,000 "readers" is purely conjectural and arbitrary. Even if, for the moment, the figure of ten readers for every subscriber and the consequent total of 180,000 are accepted, i.t would mean in effect that an inordinate number of the estimated total literate population of the Peninsula at that time read periodicals. There is no evidence to sustain this proposition.

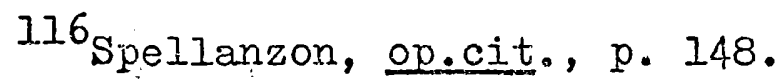

117 Greenfield, op.cit., p. 191.

118 "Bulletino," Annali, 1833, p. $244 \mathrm{ff}$, quoted in Greenfield, op.cit., p. 191.

119 Greenfield, op.cit., p. 191. 
To reiterate, the overwhelming "...mass of the people in Italy was agricultural." 120 Many of them were illiterate, mostly bound to the land in a rigid dawn-to-dusk schedule six days a week and sometimes on Sundays, too. They were unused to the jourmalistic approach, and "...the periodicals in Italy were in their infancy. "12I

And even if the periodicals were read to some of the illiterate peasants and artisans in the communal reading rooms (and "...these were relatively few in numbers, "122), or around the fire in the cascina, the act of understanding "between the lines," required a certain degree of intellectual sophistication. But; of course, the peasant's daily heavy burdens left little time or energy for political dism cussions and "readings"--even if he were interested.

Then, too, it was common knowledge that "... spjes lurked about in cafes, theatres, and other public places, "I23 and surely the reading rooms were included on the list. These spies were ever ready to report to the authorities the least "suspicious" act. It is safe to assurne that not nany persons were likely to be found flirting openly or very long with such a dangerous temptation.

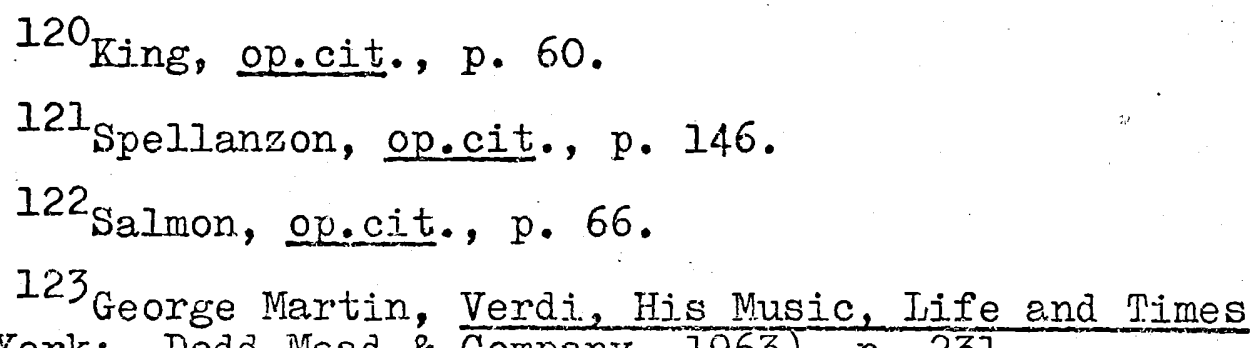


In another proposition of his thesis, Greenfield appears to give a large share of the creajt to the lombard journals for eventually bringing about the institution of Scientific Congresses in various parts of the Peninsula beginning with Pisa:

The Scientific Congresses which began to meet in 1839 were the natural crown and fruition of this iournalism and of the association and ideas that it promoted... The Annali in April, 1831, reproduced an article by Mayer from the Antologia advocating conventions of scientists and seconded the proposal. In 1833 it published a letter from a correspondent who had attended a congress of scientists at Cambridge, England. 124 [italics mine.]

To postulate that the Scientific Congresses-athe first one in 1839 -were a result of two articles, one in 1831 and again one in 1833 (meager reporting to be sure) published in the Annali, does not appear valid. As in the case of several other institutions coming into being in the Peninsula in the late 1830's and into the 1840's attributed by Greenfield to the influence of the periodicals, one cannot assume that sequence of events means or implies a necessary cause-and-effect relationship, certainly even less so when the time element involved spans almost a decade and the proposition is based only on two "reportings." Besides, a reportex of that same Iombard journal, commenting on the Congress after the event, represented the "...first meeting at Pisa as a love-feast of Italian pride and fraternity... 
attributing its success to Leopold II. "125 [Italics mine.]

125 Annali, 1839, IXII, p. 289, quoted in Greenfield, op. cit., p. 279. 


\section{CHAPTER IV}

\section{CONCIUSTON}

\section{SUIIVARY}

The Lombard journals, upon which Professor Greenfield based his thesis on the effectiveness of "national journalism" in the formation of the Italian national spirit, oper.ated under many djverse and blunting burdens which included those of: (I) Censorship, of varying degrees, both of govm ernment and Church; (2) An overwhelming peasant population bound to the land in a rigid dawn-tomdusk schedule--a popum lace almost entirely illiterate with little hope or opportunity for any education to any appreciable degree; (3) A population divided by innumerable highlymdifferent dialects with as yet no recognized national language; (4) Political inertia and a lack of interest in governmental affairs; (5) Regional antipathies that went back to centuries in some cases, due to many reasons, e.g., accidents of his. tory or geography or racial mixtures, etc.

From Professor Greenfield's study it was found that there were no newspapers as such on the Feninsula, only biased official gazzettes and some 90 periodicals. From the few Lombard journals, he chooses three as illustrative and most effective organs of "national journalism." These deal 
mostly with foreign reviews, or Italian reviews of foreign Jiterature, or used the leaded language of statistics and technology--a "code" understood by a small group of intellectuals.

Furthermore, the periodicals had collaborators and financial difficulties; there was a dearth of native journalists; and because the organs borrowed heavily from foreign journals, and one of them--the Politecnico--was almost wholly concerned with Iombardy, the journals to a great extent lacked Italianita. Corresponderce to and from many areas of the Peninsula -...over half-was jmpossible; and that circulation figures were poor, and hardly indicative of "national journalism."

Professor Greenfield attempts to credit the success of certain specific institutions to the work of the journals, e.g., the Scientific Congresses; but no place in the thesis was evidence found for a cause-and-effect relationship between the printed word and the specific event.

\section{CONCLUSION}

In view of the foregoing, it is reasonable to conclude that the lombard journals--so few in number, so poor in circulation, and operating under diverse and blunting burdens, had some effect possibly on the formation of the Italian national spirit, but not to the degree postulated by the Greenfield thesis. At best, they influenced a small "ingroup" of liberal intellectuals made up of a small minority 
of the middle class and enlightened aristocracy, many of whom corresponded with one another, and wrote for each other's periodicals--in a kind of intellectual incest. Romagnosi is described as a

...kind of socrates, who inspired with ardent de-votion a group of young men that included some of the best of the generation coming of age about 1830-most eminent among them Carlo Cattaneo, Giuseppe and Defendente Sacchi, and the fiery Cesare correnti. Gathering these young disciples about him as collaborators he converted Iampato's periodical jnto the organ of a philosophy of patriotic social action.

Not oxily did the journalists write for each other's period-icals as well as read them, they lived and wrote in lombardy most of their lives. This is another factor that bolsters this paper's contention that the Lombard journals were not national in scope, and that they did not appreciably help develop an "informed public opinion all over Italy," thereby becoming a formidable influence in the formation of the national spirit.

At best, the few journals were but a small segment of many other influences and changes taking place all over Europe and in a few places in Italy. Professor Greenfield does recognize some of these other influences, e.g., literary Romanticism, the so-called "primary works" of the Risorgimento, nationalism, industrialization, and later on in the period the "conversion" of Charles Albert and the election of the "liberal" Pope Pius IX--but he gives to the

$$
126 \text { Greenfield, op.cit., p. } 166 .
$$


Lombard journals and to their influence an importance which this paper, in view of the foregoing, questions.

There was one event that occurred relatively early in the 1830-1848 period which had far-reaching effects not only on Europe but also on the Peninsula, particularly in Lombardy-Venetia, and which was not mentioned in the Greenfield. thesis, and that was the death, in 1835, of the Austrian Emperor, Francis II.

It removed a narrow bigoted bureaucrat who, impervious to new ideas freferred obedience to education and a police barracks to a university... the personality of an Austrian Emperor was of greatex importance than that of any other ruler in Europe, and the fact that the son and heir of Francis II, Ferdinand, was mentally deficient and a mere figurehead, was a tragedy for the Empire. A brave face, however, was put upon a bad si.tuation and for 13 years the Empire was governed by a triumvirate: Metternich, Count Iolowrat and the Archalke Louis... the effect of this new state of things, wass $_{\text {to }}$ impose on Metternich a policy of peace. [ftalics mine.]

And not only a policy of "peace," but of tolerance of a few changes that Metternich knew would inevitably filter into" the Perinsula, e.g., the Scientific Congresses, the adult education series, the talks of Richard Cobden in Milan, etc.

Very important to note is the fact that Greenfield takes no notice of the enzymatic influences of the Romantic theatre--drama and opera-discussed below, nor the potent- . ialities of the folk-song at night around the fires of the cascina, discussed earlier, towards development of the national spirit.

1.27 Whyte, The Evolution of.... p. 44. 
The Romanticism of the theatre was considerably different in genre from that of the historical novel, or poetry, for the theatre had-and has-ma direct and immediate emotional appeal even to the unlettered; whereas, Manzoni's fiction and Leoparai's poetry, for instance, required not only literacy, but also a certain developed aesthetic taste on the part of the reader.

The so-called Grand Tour was another "institution" not mentioned by Greenfield and which had some effect on the minority of liberal thinkers. This tour of kurope (which always included Italy in the itimerary) was taken at this time usually by members of the English aristocracy and some of the upper middle class merchants, for recreational as well as for prestige purposes. "Ihe Grand Tour made for ease not only in the transmission of taste, but also of ideas. "128 Therefore, in view of the foregoing, that part of the Greenfield study that states that through the medium of the journals (I) an Italian public opinion had been formed; (2) that the public had been indoctrinated with a new con-ception of their interests in 1848; (3) that Italian journalism had become a major force in shaping the national program must be rejected. In the case of at least one of the three journals--the Politecnico--, rather than contributing to the formation of the national spixit, aided in the development of regionalism.

128 J. H. Phimb, "The Grand Tour," Horizon, II, No. 4 (November 1, 1959), p. 73-104. 


\section{PART II THE THEATRE}

\section{CHAPTER I}

\section{INTRODUCTION}

In considering the effectiveness of the Italian theatre in the formation of the national spirit, 1830-1848, it is necessary to go back to Vittorio Alfieri, 1749-1803, who wrote tragedies towards the end of the $1700^{\prime} \mathrm{s}$; also, to such playwrights a.s Ugo Foscolo, 1778-1827, Silvio Pellico, 17891854, and A.lessandro Manzoni, 1785-1873, all of whom wrote tragedies in the early $1800^{\prime} \mathrm{s}$, but whose plays, along with Alfieri's, were performed before, during and after the 1830 1848 period. Pellico wrote a few plays after 1830 upon his return from Spielberg, but none of them are worth noting. Gianbattista Niccolini, 1782-1861, was the only tragedian of importance writing in the period under consideration.

Music--opera--at this time is considerably restricted in output, yet somewhat paradoxically. it may have had the greater effect. A consideration of "nationalistic" music at that time almost exclusively involves Giuseppe Verdi, 18131901, and his several operas written before 1848, and the composers Giacomo Rossini, 1792-1868, and his opera, William Te11, 1829, performed mostly abroad but sometimes in the 
Peninsula as well, and Vincenzo Bellini, 180l-1835, and one or two of his operas.

It is demonstrable that the drama with its immediate play on emotions, and music "... with its direct appeal to the passions of the people, "129 were instrumental to an appreciable degree in helping to form the Italian national spirit.

The spectator as he enters the theatre becomes a partner to convention in order that the drarna can take place, i.e., "he enters into the situatjon imaginatjvely by what Samuel Coleridge termed in his Biografia Letturaria, a '...willing suspension of disbelief." 130 The immediacy of flesh-and-blood reality on stage creates an impelling "nowness," and depending upon the subject matter and its clarity of communication, the spectator cannot but be moved to reflection or action or both.

Music can have a startling effect on an audience, especially to an audience as accustomed to this medium as the Italians were and as they are today. When music is used to reiterate--indirectly--injustices of an oppressed people longing for deliverance, that medium so used can pose problems for the oppressors. "Music is essentially a play upon feeling. It is appreciated only insofar as it arouses feeling and can be expressed only by active and very intense

${ }^{129}$ Crawley, op.cit., p. 129.

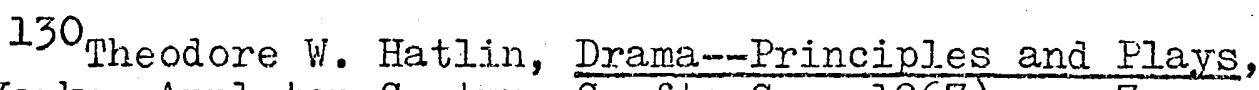

(New York: Appleton-Century-Crofts Co., 1967), p. 7 . 
feeling." 131

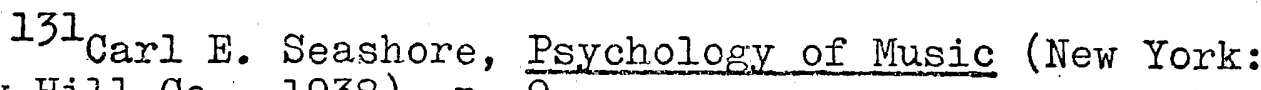
NicGraw-Hill Co., 1938), p. 9. 
DEFINITION

For purposes of this paper, the term, "theatre," is understood to include Italian operas as well as Italian tragedies. While the vogue of tragedy prevailed in Italy, comedy suffered neglect. "A few insipid imitators of Goldoni produced comedies, but iittle wortin of survival." 132

${ }^{132}$ Phyllis Hartnoll (ed.), The oxford Companion to the Theatre (London: Oxford University Press, 1957), p. 405. 


\section{CHAPTER II}

\section{THE DRAMA: A BRIEF SURVEY}

Most of the literature and especially the drama in Italy in the first half of the 19.th century can hardly be separated from politios and patriotism. It might better be said that "Italian" literature in that period went hand-inkand with politics: "If the poets, dramatists, corposers of Italy did not create the Risorgimento, they at least fostered it."133

With few exceptions plays of the early 19th century in Italy belong to the history of literature rather than to the history of the theatre. In some cases the drama represents the mediocre achievement of poets or prose-writers who made themselves famous for excellence in other genres, e.g., Silvio Pellico and Alessandro Manzoni. That some rulers of the states of Italy wanted to encourage drama and improve the quality of its output is indicated by the number of prizes offered for the best plays.

From 1770 onwards, the Duke of Parma offered annually a prize for the best tragedy. In 1786 this was won by Vincenzo Monti, 1754-1828, the most representative dranatist of Italy's Napoleonic era, but not of the class of Risorgimental authors, e.g.,

133 N. J. Perella, "Italian Iiterature," The New Catholic Encyclopedia ed. William J. McDonald, VII (I967), p. 301. 
Silvio Pellico. 134

Influential in helping to form an awareness of nationalism was the Fiedmontese Vittorio Alfieri from whose tra-gedies emanated a hatred for tyranny and tyrannical kings; his yearnings for freedom form the basis of much of his dramatic work. Alfieri's love for freedom "...inspired him to dedicate his tragedy, Bruto I, 1787, to the 'Iiberator of America,' George Washington." 135

In plot, speeches and even in number of characters, Alfieri limited hirselif to whatever was strictly necessary to the fundamental dramatic conflict, creating a theatre that is "... Iean and stripped to its essentials... and because of its brevity and compression, often severe in expression."136 Alfieri preferred to take his plots from historical events and classical myths.

Among Alfieri's most important works are: Filippo, 1771, Virginia, 1778, Saul, 1782, Mirra, 1784, Bruto I, 1786, and Bruto II, 1789.

His characters are figures of superhuman dimensions who struggle among themselves or against a fate stronger than they. They possess grandeur and classic virtues which Alfieri saw as positive ideals and which he contrasted with the servile softness of his society.

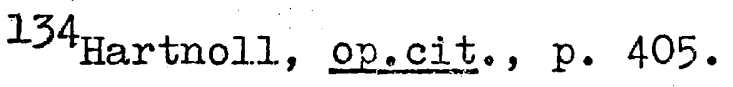

135 Perella, op.cit., p. 303.

136 John Gassner and Edward Quinn (eds.), The Reader's Encyclopedia of World Drama (New York: Thomas Y. Crowell.. Co., 1969), p. 13 . 
But Alfieri was writing at the end of the neoclassical tradition. Although his plays served to revive the national spirit in Italy and continue to be highly regarded by some, they, have had little influence on subsequent writers.

Ugo Foscolo, born of a Venetian family living on the Greek Island of Zante, is the next playwright of any note following Alfieri. In 1797, he dedicated to Alfieri the Tieste written in Alfierian style. "This play has a broad. political purpose."138 The lead, Tieste, is the vindicstor of justice and liberty. Next came Ajace, an ambitious but dull attempt to portray anew the age-old story of tyranny and oppression based on the classical myth of Ajax.

He welcomed the coming of Napoleon with an ode entitied Bonaparte liberatore, but he was soon bitterly distressed by the cession of Venjce to. Austria and by the abject passiveness with ghich $_{9}$
Venice sank into a new provincjal status.

He left Venice and made his way to Milan and eventually to Florence where in 1813 he wrote his last tragedy, the Ricciarda which was eventually printed in Iondon. This is a story of two brothers who for many years struggled for the paternal inheritance, which one brother would not agree. to divide with the other, as their father had decreed.

In 1815, faced with the necessity of taking an oath of allegiance to the Austrian regime if he were to remain in

137 Oscar G. Brockett, The Theatre--An Introduction (New York: Holt, Rinehart \& Winston, Inc., 1969), p. 214.

138 Joseph Spencer Kennard, The Italian Theatre (New York: William Edwin Rudge Co., 1932), p. 226.

139 Ernest Hatch Wilkins, A History of Italian Iiterature (Cambridge: Harvard University Press,.1966), p. 379. 
the province, Foscolo preferred voluntary exjle, and fled to Switzerland, and eventually to Iondon where he spent the rest of his life. He wrote no more Italian poetry or plays. "He seemed to be in exile not only from Italy but also from Parnassus." 140

Silvio Pellico's claim to fame rests on his work with the famous II Conciliatore and for his memorable book, I miei prigioni written upon his release from spielberg. His plays, some ten in number, are not worthwhile, with the possible exception of his Francesca da Rimini, 1815, based on the story of Darte's Inferno. At the time, Francesca as a play "...had tremendous success, yet the plot j.s weak, the versification poor, and there is some ranting and ruch padding. "141

In the second scene of Act I of the play, there occurs the first tirade which became a kind of war cry for years in various parts of the Peninsula:

For whom was my sword tainted with biood? For a strangex? Have I no country for whom her sons' blood should be sacred? For thee, for thee, my Italy, will I henceforth fight, if outrage is done to thee by envy.

Pellico's career in playwrighting was jus t getting started when he was sent away to Spielberg Prison for almost a decade, and upon his return in 1831, Pellico under

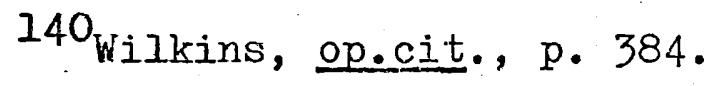

${ }^{141}$ Antonio d'Ancona, Origini del teatro Italiano (Torino: Bocca, 1891), p. 230 .

${ }^{142}$ Silvio Pellico, Francesca da Rimini, quoted in Wilkins, op.cit., p. 414. 
went great psychological and spiritual change, so that "it is impossible to evaluate his potential as a dramatist." 143 The plays that Pellico did write are now considered by critics to be boring exercises in verbosity, structured with poor technique and generally devoid of any inherent artistry. Alessandro Manzoni, born in Milan, was "...modest, chaste and beloved."144 He was also timid and hated crowds. His life was plagued by the early deaths of those he loved, for both his wives and one of his sons died before him. He was better known as a novelist and poet than as a playwright; His novel, I promessi sposi, remains "... soli.tery glory as Italy's great prose mastexpiece." 145 Manzoni did not begin his first drama until 1816 and was four years in writing it.

I] conte di Carmagnola, 1820, was a Iyrical historical tragedy, romantic in style and religious in feeling, showing influences of. Schiller's Wallenstein. Adelchi, 1822, lacks unity and force, Manzoni was probably wige in not again attempting the dramatic form.

Manzoni made the hero of Carmagnola a Condottiero of the 15th century who, though innocent, was put to death by the Repiblic of Venice. Manzoni believed that by a vi-

${ }^{1} 43$ Colby Kunitz, European Authors (New York: H. W. Wilson Co., 1967), p. 7i.1.

144 Domenico Vittorini, High Points from History of Italian literature (New York: David McKay Co., 1958), p. 181.

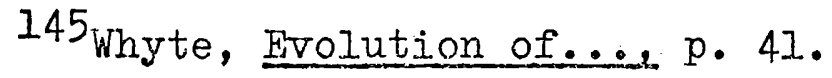

146 George Freedley and John A. Reeves, A History of Theatre (New York: Crown Publishers, 1941), p. 440 . 
sion of such shocking injustice, he could raise the mind of the spectator to the thought of God. But the tragedy lacks dramatic force because there is no real conflict. The judgment of Carmagnola is pronounced in his absence by the Venetian senate, and he even eventually accepts his condemnation with resignation.

In his tragedy, Adelchi, 1822, the playwright repre-sented a generous Lombard prince who is forced by his family ties and prejudices to undertake personal. vengeance and to continue the war against the pope, although he would prefer to support the Church and the oppressed Italian people. "The tragedy has momerits of great beauty which are perhaps more lyric than dramatic." 147

Gianbattista Niccolini, born in a town near Pisa, served more than fifty years as Professor of History and Mythology in the Florentine Accademia de Belle Arti. The desire to write tragedies came to him from his acquaintance with classic tragedy, and his own first plays written in the years 1810-1814 are greek in subject and strictly neoclassic in form. "In 1810, his tragedy, Polissena, was awarded a prize by the Crusca. "148

In his Nabucco ("Nebuchadnezzar"), written in 1815, Niccolini takes a new direction: for his nominal Nebuchadnezzar represents Napoleon, and the play is an attack on

$147_{R}$. Montano, "Manzoni," The New Catholic Encyclopedia, ed. William J. McDonald, VIII (1.967), p. 232 .

${ }^{148}$ Lacy Coliison-lorley, Modern Italian Iiterature (New York: Little Brown \& Co., 1912), p. 255 . 
despotism.

All of the eight tragedies that Niccolini completed thereafter are medieval or modern in subject, and in all of them, largely as a result of admiration for Shakespeare, Byron, Schiller and Manzoni, he adopts in varying degrees the increasingly Romantic attitudes and methods. Four are plays of tragic love; the other four are primarily political in purpose, and draw their subjects from crilical moments in the age-Iong Italian struggle against despotism: Giovarni da Procida deals with the Sicilian Vespers of 1282; Iodovico sforza with the Milanese tyrant whose invitation to Charles VIII brought the beginning of foreign domination; Arnaldo da Brescia with the hero of a twelfth century Roman republican revolution; and Filippo Strozzi with the final. establishment (after Iorenzino's assassination of Duke Alessandro) of the line of ducal Medici.

The Arnaldo, printed in France in 1843, and circulated clandestinely in Italy, is perhaps the best of all these tragedies. The protagonists are the fearless monk Arnaldo who represents the cause of Italian freedom and unity, the English Pope Hadrian IV who represents the papal claim to temporal power, and the Emperor Frederick Barbarossa, who represents the imperial claim to absolute dominion. Only a consummate playwright could do justice to the clashing of these three titans and their titanic forces. "Niccolini was by no means a supreme dramatist, but he does his loyal best with his great theme, and the resulting play has much 
nobility." 149

Of course, the re were other functioning playwrights at this time, e.g., C. Tebaldi Fores, Giuseppe Rovere, Stanislao Morelli, etc., but their works bear the unmistakable mark of mediocrity, and history has recorded little else about them.

For all intents and purposes, what might be called Risorgimental opera, 1830-1848, was dominated by the music of Giuseppe Verdi, and by one or two operas by the composers Giacomo Rossini and Vincenzo Bellini. "Rossini had finished his operatic life in 1829 with the cornosition of William Tel1, "150 With him closed a period of Italian music and forthwith came the dawning of a new age in Italian opera represented by the prodigious works of Verdi. Bellini had died in 1836, and Donizetti was at the very end of his career--his last important work, the brilliant comic masterpiece Don Pasquale dates from 1843. How ever, neither Bellini nor Donizetti can be called "nationalistic" composers as such (except in one or two instances), since their operas are more in the style of the neo-classic, graceful and elegant piece.

The plot of Rossini's William Tell, 1829, centers a round the struggle of Swiss cantons for independence, and extols the vindicator of Swiss national freedom. The li-

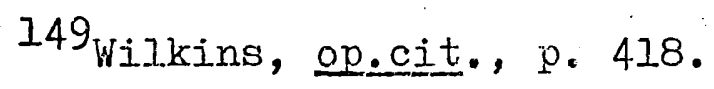

150 Gerald Abraham, A Hundred Years of Music (Chicago: Aldine Publishing Co., 1964), p. 79. 
bretto describes-rather too elegantly-the tragedy of a man who taires upon himself the tragedy of a people yearning for independence.

\section{Bellini's opera, I puritani e i cavalieri, performed} for the first time in the Theatre Italien in Paris, 1832, when played later in some of the states of the peninsula prom vided a dramatic situation from which political allusions to the present conditions could apply.

Giuseppe Verdi was born, then, in a period of transition in Italian opera. The gxacefu] styles of Donizetti, Bellini and Rossini were cultivated by innumerable minor composers and the imitations were highly infexior works, with none of their models' true elegance. "It is remarkable that, after a few false starts, Verdi was abje to find his own way regardless of the models before and around him."15I

Verdi's first real success which brought him to the fore and spread his name through several of the states of the Peninsula was Nabucco, first performed in 1842 in Milan. The story tells of the fortunes of the Jews during the BabyIonian Captivity; the possibilities for political allusion can be readily seen. There can be little doubt, especially in view of Verdi's later support of Cavour, that he was using opera at this iime also as a vehicle for patriotic sentiment when the occasion suitably presented itself.

The next two operas, I Iombardi, 1843, and Errani,

${ }^{151}$ Domenico Meccoli, II Risorgimento Italiano nel teatro e nel cinema (Roma: Rditalia, 1961), p. I1.9. 
1844, also had revolutionary undertones, and in these works the powerful'combination of great choruses and political alIusion aroused intense enthusiasm and contributed to the speed with which these operas were taken up by many theatres in the Italian states. Then in quick succession came I due Foscari, 1844, Giovanna d'Arco, 1845, and Alzira, 1845, none of these three are up to the standard of his great masterpieces. These were followed by two more "political" operas, Attila, 1846, and Ia Battarlia di Legnano, composed in 1848 and first given performance in January, 1949, in Rome. With La Battaglia di Legnano, Verdi glorified the struggle of the Milanese against Emperor Barbarossa, and thus provided a wealth of allusive phrases for the liberal cause for freedom.

The words, 'Viva Verdi' which appeared almost everywhere were generally assumed to replace the forbidden 'Viva I'Italia' and later when Victor' Emanuel, King of Sardinia, had been offered the throne of a united Italy, people saw a symbol in Verdi's name-the acrostic Vittorio Emmanuele Re d'Italia.

Verdi's work can be appraised also as a stage in the development of operatic realism. With him, opera began to be engaged in the task of "...putting flesh and blood upon typical events and personages of history, and history itself was seen in terms of its lessons for the struggle in behalf of progress." 153 Clearly, Verdi was eager to create 152 Seashore, op.cit., p. 293. ${ }^{153}$ Paul Henry Lang, Music in Western Civilization (New York: W..W. Norton \& Co., Inc., 194I), p. 938. 
operas about political ideas--but with the reservation that the politics had to be turned into the atuff of art; he was keenly aware of the drama of human relationships. 


\section{CHAPTER III}

THE THEATRE PROBLEN: AN ANALYSIS

Politics in a work of art is like a pistol shot in the middle of a concert, something loud and vulgar, and yet a thing to 1 hich it is not possible to refuse one's attention.

The theatre problem, 1830-1848, involves the question: to what extent did the tragecies and operas of that period assist in communicating to their respective audiences a sense of national consciousness, of a developing national spirit? In this connection these factors ought to be taken into consideration: (1) Censorship and related problems; (2) Attendance and opporturities for performances.

\section{CENSORSHIP AND REIATED PROBLEMS}

Many instances oif mutilations of manuscripts and scores --even cancellations and general prohibitions of performances are recorded by various authors. The censorship mainly emanated from the government; however, at times the Church hiexarchy also placed restrictions on scripts, e.g., the objection of the Archbishop of Milan to a scene in Niccolini's Arnaldo da Brescia in which a re-enactment of a baptismal ceremony was called for on stage.

${ }^{154}$ Irving Howe, Politics and the Novel (Greenwich, Connecticut: Fawcett FubIications, 1957), p. 17 . 
The Italian thegtre during the first half of the 19th century was one of several forces in the process which ultimately helped develop a national spirit. It succeeded in providing a dynamic medium for the diffusion of patriotic ideals-mainly by indirection, and in creating an atmosphere of passion which "... sharpened the moral sense of the spectators, appealing to them as Italians, even though they were still divided politically."155 A theatrical writer, and especially an actor, at a given time and place

...can put over an impression, comminicate feelings, cause a reaction by the playing of a situation on stage, through the allusive gesture, through controversial tone, rather than by the word and its literal meaning. And the audience in a receptive frame of mind, immediately understands the code language and responds spontaneous 158 thus establishing a dialogue between them.

The story of the Italian theatre is really the story of this subtle and allusive dialogue whose collaborators gradually emerged as the Risorgimento developed. On one side there was the sensitivity of the spectator becoming quicker. and more acute, and on the other, the writers and actors had more frequent and easier opportunities of communicating their message. A pause, a gesture, a vague reference were enough to make the point intelligible.

Some plays became famous; they assumed a symbolic value in the Risorgimental struggle just through one scene or even

155 Archibald Colquhoun, Manzoni and His Times (London: J. M. Dent and Co., Itd., 1954T, p. 82 .

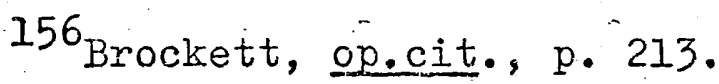


one line, e.g., Pellico's Francesca da Rimini. They were part of the "...Romantic Movement which elsewhere on the Continent told in favor of reaction, but in Italy became the handmaid of revolution."157

The theatre has always been popular in Italy, even though it has more often than not, been less than great, even mediocre. Much of the social life there centered around the theatre and the opera houses, so that the daily Iife was infected with much of the artificiality of the stage.

In his Italian Journey, the German poet Goethe who was in Venice in 1787, has left an eye-witness description of the Italian theatre of that period. He tells how the spectators join the play like children shouting and clapping. The theatre presents the life they know.

The realization that composers could write music infused with the very spirit of a people and founded on the tunes known to everyone helped instil the beginnings of national consciousness and a certain sense of destiny "... that made of fullest effect the 'purposeful current of propaganda' set in motion by the leaders of the thought of the times." 159 The tragedies of Vittorio Alfieri give some idea of the phenomenon by which a play becomes the pretext to ex-

157 Edward Dannreuther (ed.) Oxford History of Music Vol. VI: The Romantic Period (Oxford: At the Clarendon Press, 1905), p. 246.

158 John A. Crow, Italy--A Journey Through Time (New York: Harper and Row, Publishers, 1965), p. 323 .

159 Howard D. McKinney and W. R. Anderson, Music in History (New York: American Book Co., 1940), p. 703 . 
press a meaning that springs directly from the rapport between footlights and stalls.

Alfieri's tragedies, covering much of the entire historic range of the Risorgimento, were often produced, and, because of the circumstances of the times and the desire on the part of many of the spectators to read into his tragedies all manner of allusions bearing on the political situation of the Peninsula, gradually became enriched by a deeper moral content and more and more satisfied the intense concern of the spectator and met many of his more urgent and harrying demands for political propaganda. The basio theme which seems to have been the inspiration of the tragedies themselves was: the mighty struggle of the individual who years for freedom against the oppressor. Alfieri was the first playwright to give dramatic play to the small. but nascent fieeling of Italian nationalism.

Alfieri's nationalism had a completely different orientation from that of his predecessors... through his pride in the Italian language, his attempts to create a native theatre, and his recognition of Dante, Alfieri amplified and strengthered sentiments which had been slowly maturing throughout the 18 th century. With his revolt against tyranny and his demand for a united nation which would guide all peoples to liberty, Alfieri presaged the 19th68entury and paved the way for the Risorgimento.

The oft-conflicting feelings of revolt, of redemption, pride and dignity, exasperation and intolerance, of injustice, which are churned together in the upheaval of the Risorgimento, have a common denominator with Alfieri's themes. ism (New York: Columbia University Press, 1951), p. 150-51. 
The name of the author alone was enough to give a controversial tone to the production, and "...for the patriots just to name him made them feel proud to be Italians."16I During the Cisalpine Republic the most frequently produced of Alfieri's tragedies were those with a republican flavor.

On the 22nd of September, 1796, Alfieri's Virginia was performed at the Canobbiana Theatre in Milan to celebrate the beginning of the fifth year of the French Republic. Among the specta-tors who danced the 'Carmagnola' in the aisles during the integyals were Napoleon Bonaparte and Josephine.

As the years went by, the attacks on despotism and tyranny which had accompanied the ascendancy of Bonaparte, in the name of revolutionary fxeedom gradually boomeranged against him. The ideal of an integrated "Italian" liberty began to be somewhat outlined. The feeling of freedom became firmer in a sense; it adapted itself closely to the special circumstances of the political situation on the Peninsula, and it may be said that the theatre contributed decisively to this evolution.

The next playwright of any note was Ugo Foscolo, a disciple of Alfieri. "As an ardent patriot, Foscolo dreamed of a day when Italy, then split into small states under Austrian dominance, would be total.Iy unfettered and uni-

161 Francesco de Sanctis, Saggi critici (8th ed.; Napoli: Tipografia del Fibreno, 1893), p. 190, quoted in Noether, op.cit., p. 109.

162 Meccoli, op.cit., p. 123. 
fied." 163

The different retaliatory feelings which can be assumed in the changed political climate, by the same plays which first appeared in the hopeful and enthusiastic atmosphere of the beginning of the Napoleonic ascent are clearly shown in Tieste, the first of the young Ugo Foscolo's tragedies. "It was performed for the first time on Jaruary 4, 1797, in the San Angelo Theatre in Venice. "1.64 The story is mythological, but political sentiment is present here and there. Atreo, the antagonist, represents divine right-mabsolutism; Tieste, the protagonist, represents revolution.

The atmosphere of Venice was red-hot. Anti--government epigrams became ever more numerous and whispered from ear to ear, they spread like wildfire. Some of them were attributed to Foscolo, and for that reason, in April, 1797, he, cau-

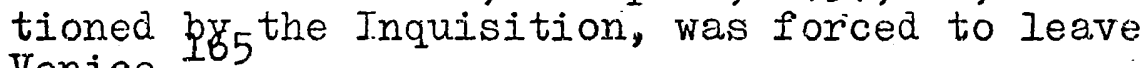
Venice. ${ }^{\text {Pr }}$

More than ten years later, in August, 1808, "... Tieste was performed at the Carcano Theatre of Milan...," 366 and on that occasion this play became the subject of a long correspondence between the Minister of Internal Affairs and the Chief of Police. The Minister of Internal Affairs in-

163 C. Cecchetti, "Ugo Foscolo," The New Catholic Encyclopedia, ed. William McDonald, V (1967), p. 331 .

${ }^{164} \mathrm{C}$. Albicini, Politica e storia (Bologna: Zanichelli, 1890), p. 672 .

${ }^{165}$ Bernard Wall, Alessandro Manzoni (New Haven: Yale University Press, 1954), p. 26.

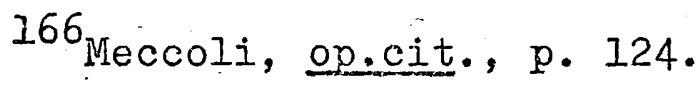


quired if there was any truth in the allegation that plays had been performed at the theatre containing aliusions which were offensive to the government. The Chief of Police re-plied that there was none of this as far as he knew ever shown for public spectacles on the Milanese stage.

He went on to say that there was an especial difficulty with respect to the theatre and this stemmed not so much from the plays themselves, but rather from the people who attended these spectacles some of which appeared to have had no other aim than to wrack their brains in order to find wi.th difficulty, 'and in spitby of commonsense,' some malicious application.

At the end of this correspondence the play, Tieste was banned.

A play, written scarcely ten years previously to herald Napoleon's entry into Italy was censored and banned by the Napoleonic police. In the years between, on the one side, the real interest of French policy was revealed, but on the other side, the audiences had reached such a reaction pitch that in almost every play performed the elements which could refer to the new situation were underlined now and again in controversial ways.

... in this active rapport between the stage and the stalls, in this 'wracking of brains' is contained the most aggressive element of 6 the theatre's role in the developing Risorgimento.

Gradually, the plays appeared in a new and different light to their respective audiences. A kind of fine and in-

${ }^{167}$ Cecchetti, op.cit., p. 332.

168 McKinney and Anderson, op.cit., p. 704. 
visible net slowly entwined itself around many parts of the Peninsula, and the police were largely unsuccessful in loosening its bonds.

The performance of dramas is not, in itself, objectively censurable, nor can spectators be accused for their displays of agreement witb what is said on stage, nor for their applause.

The police, without anything definite to go on, had to accommodate themselves accordingly.

It was a kind of game played between the artists and the police, and it is difficult to reconstruct in all its facets; and there is no real definitive explanation to account for the extraordinary fascination wielded by some plays and actors and the political and moral importance they assumed. But they did make up the basic elements in this dangerous and delicate game. In the case of rieste, they revived a tragedy whose past seemed to be above reproach, but in a changed political climate the play became controversial; the actors helped because in theix playing of the drama they underlined those words, verses and gestures which were fraught with criticisms--indirect, allusive though they were--of current events.

"Foscolo's second tragedy, Ajace, performed at Ia Scala, December 9, 1811, was also put under police surveillance."170 In this piece, it could be implied that the tyrannical Agaememnon represented Napoleon himself. The

169 MTeccoli, op.cit., p. 124.

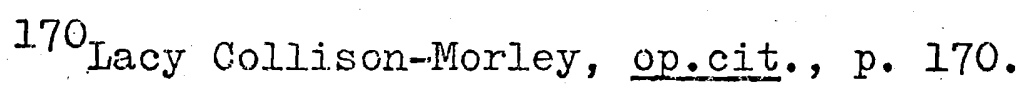


tragedy was banned soon after its opening, not only in Milan but in other parts of french-Italian provinces as well. As far as is known, the playwright never admitted that the allusions possible in Ajace were intentional. But, at any rate, the tragedy was not performed again, and Foscolo left Milan--probably at the request of the police.

In 1815 Foscolo found he would be obliged to take an oath of loyalty to the restored government, and he refused. By this action, Foscolp gave the new 'Italy' a new institution--exile.

Foscolo's plays were performed rarely in the 1830-1848 period; however, when they were allowed they sometimes provoked audience reaction with political overtones, as in the case of the performance at La Fenice teatro in Venice, 1839.

In the meantime, differences of opinion flared up be-tween the followers of Classicism and the supporters of the new Romanticism. "This was primarily a European controversy; however, when it reached Italy, it mirrored the Peninsula's particular political situation."172 After the kestoration, conservative Classicism became the banner for the supporters of the returned rulers, while Romanticism--the despoiler of tradition-claimed the new generation, often rebellious of the ties to the past.

But the distinctions were not always so sharply de${ }^{171}$ Lacy Collison-Morley, op.cit., p. I7I. $172_{\mathrm{E}}$. R. Vincent, Byron, Hobhouse and Foscolo (Iondon: Cambridge University Press, 1949), p. 153. 
fined, and particularly, not in the world of the theatre. The most important symbol of the spirit of Classicism in dramatic Iiterature was Vittoxio Alfieri who was both a flagwaver for liberty and a precursor of Romantic pathos.

Classicism and Romanticism came together not infre-quently on the stage, and found a point in common in the more or less open glorification of patriotic iaeals which for quite some time up to 1848 constituted one of the dominating features of the better and more dynamic Italian dra matic Iiterature.

Slowly there developed a type of tragedy which could best be described as Risorgimental. Stamped ever more clearly by the influence of the Romantic dispute---the destroyer of the classical myth of the dramatic unities--it revived interest in national-o istic subjects. This tragedy was inspired by Medieval historic events. And naturally it first selected those which could be adapted to a contemporary reconstruction, accentuating the remote aspirations of the 1 ggople to independence from foreign domination.

The first truly Risorgimental play was Francesca da

Rimini by the 26-year old Silvio Pellico.

Performed first at the King's Theatre, Milan, on the 18th of August, 1815, da Rimini, with the famous Carlotta Marchionni in the title role, was warmly received and presented in several other major theatres of the. Peninsula; it brought fame and success to its young author, 174

The emotionally romantic interpretation of Dante's story, which, because of the spirit of the times, was endowed with controversial meaning, was not the only reason for its suc-

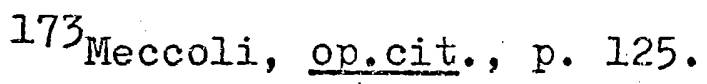

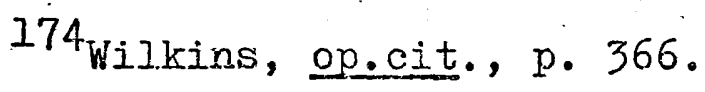


cess. "There were also allusions to condjtions in I.taly at that time."175 Francesca da Rimini was not censored until Pellico had been condemned to Spielberg Prison.

Pellico's second tragedy written before his sentence, Eufemio da Messina, 1816, was never performed. The censor banned it, defining it as "...offensive towards religion and overwhelmingly atrocious."176. Sufemio da Messina telis a gloomy story of warfare and love which took place during the Saracen invasion of Sicily in about the year 830, and its chief character clearly referring to the Austrian occupation in the 5 th Act, makes a speech in which he expresses sentiments of patriotism and loa thing for foreign domination.

In jail, Pellico wrote three tragedies: Ester di Engaddi, Iginia d.'Asti, and Leoniera da Dertona.

The first performance of Estex was an unforgettable evening, and Silvio's return was truly celebrated. And the tragedy itself did much to make the occasion even more memorable, for it seemed to the public that the character of sad Pope Iefte was a gauntlet thrown down in challenge to Rome and the Papacy. Not only was the applause long and loud, but Pellico's name was called out repeatedly, and women in their boxes waved their white hankerchiefs to welcome the freed prisoner. 177

It seemed that once more the theatre and real life had come face to face. The skow gave the crowd a chance to express

${ }^{175_{G}}$. Volpe, Italia moderna, 1815-1915 (Firenza: Sansoni, 1943), p. 112.

176 Cecchetti, op.cit., p. 334 .

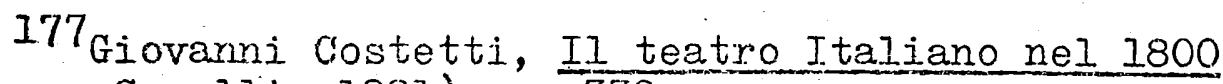
(Milano: Capel]i, 1881.), p. 338. 
its real sentiments.

In a performance of Gismonda da Menrisio which appealed even more to public feeling because of the hatred it expressed of Barbarossa and the imperialists, the whole audience rose to its feet, including the ladies in the boxes. Ihere were yells and shouts of approval. Hankerchieis were waved like flags; flowers thrown on $f_{f}$ stage to Mme. Narchionni as well as the cast.

In Iginia d'Asti, as well as with Ester di Engaddi, 1831, the background is the struggle between the Guelphs. and Ghibellines; in Ieoniero da Dertona, 1832, the civil discord of the Middle Ages was presented.

...to give the message of society's need for mutual indulgence and sincere harmony between men of goodwill. The play was censored and

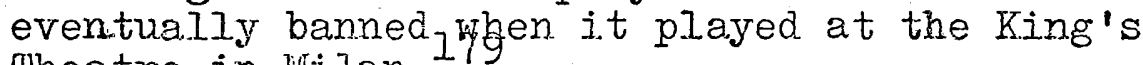
Theatre in Milan. 19

In Pellico's successive theatrical works-mhe underwent a deep spiritual transformation during his imprisonment--another theme was to become dominant: that of Christian resignation which the Italians, intent as they were on the struggle for independence, could not at that moment appreciate with equal intensity. And, in fact, the enthusiasm of those evenings in 1832 was not repeated; "...from then on Silvio Pellico was excluded from the conversation, and another of his tragedies, corradino performed by the Royal Sardinian Company in 1835, was howled down."180

${ }^{178}$ Costetti, op.cit., p. 339.

179 Licurgo Cappelletti, Storia de Caxlo Alberto e del Suo Regno (Milano: Voghera, 1891), p. 70 .

$180_{F}$. Baldensperger and $W . \dot{P}$. Friederich, "Niccolini," Enciclopedia dello spettacolo, ed. G. C. Sansoni, XI (1956). p. 404. 
Another Risorgimental tragedian is Gianbattista Niccolini, a champion behind the footlights of lay and republican liberalism. He was as fiery and violent as Pellico was emotional and subdued.

Niccolini's first theatrical experiences were with Classicism, whjch was more in keeping with his temperment. But after Nabucco, which was published anonymously in London, he became more susceptible to Romantic influences, looking back into the past with a spirit of comprehending both the past and the contemporary political struggle.

In fact, in his Nabucco, for which the author left a key so that its exact meaning could be understood, the characters represent figures of the late Napoleonic times.

Nabucco leads his people into a whirlwind of victorious battles. But he starts on the road to ruin when he decides to conquer Scizia; here the desolate snowy plains present fijs $_{\text {s }}$ army with an insuperable and ruinous barrier.

Nabucco, of course, represents Napoleon.

The tragedy, Giovanni da Frocida, first performed in Florence in January, 1830, aroused the anxiety of the government, caused a diplomatic flurry-all of which $^{2}$ resulted in its being banned until 1847 .

In this play, Niccolini was able to take a plot involving the passions of a brother and his sister who are unaware of the true implications of their relationship, and use it as a patriotic theme. The action of Giovanni takes place ${ }^{181}$ Cecchetti, op.cit., p. 334 . $182 \mathrm{~J}$. Martinengo-Cesaresco, Italian Characters (Iondon: Seeley \& Co., Itd., 1902), p. 98. 
in Sicily at the time of Vespers; but its style is very modern, not only in its contents, but also in its form that it is understandable how the audience was quickly able to pick up the clear and numerous political allusions.

When Giovanni da Procida, based on the Sicilian Vespers, was performed in Florence, the French Minister, who was present, was most indignant at the cheers which greeted the lines directed against his countrymen; but the Austrian. Minister nearby remarked, 'Don't take it badly--the envelope iff addressed to you, but the conten's are for me.

The play received "...raptuous applause whenever it was played, especially those parts having definite application for the then political circumstances." 184

In 1843 Niccolini's Arnaldo da Brescia was published in Marsejlles and Capolago. In the play, the agitator after the revolt, determines to set up a people's republic, and is shown as a martyr for freedom, fjghting against imperial tyrany personified by Frederick Barbarossa and Papal tyranny personjified by Hadrian IV.

Niccolini was one of the first to advocate Italian unity and the abolition of the temporal power of the pope. He was not anti-religious but anti-clerical, and Arnaldo da Brescia the best of his tragedies may be said to contain his political creed.

It was eagerly devoured in its day, and it stirred patriotic feelings to the depths. It was smuggled from one end of the Peninsula to another in

${ }^{183}$ Hearder, op.eit., p. 129.

184 Whyte, Evolution of..., p. 42. 
false covers... Arnaldo undoubtedly contributed to the success of the cause which its author and the men of his day had at heart. The appeals for Italian unity, e.g., Act I, Scene III, were vigorous and inspirigg and were on many people's lips at the time.

Arnaldo, because of its theme, is considered as the antidote for Gioberti's Del primato morale e civile degli Italiani, which was published also in 1843. Niccolini's tragedies drew from medieval history memories that roused the people to recollection of their old democracy, and "...his Arnaldo da Brescia was a hymn to liberty, fiercely satirizing German and Papist, and teaching how emperor and pope were leagued to oppress the land." 186

Though Niccolini displayed in his writings the transition of style in Tuscany from the Classical to the Romantic, he wrote plays of no great distinction, including Arnaldo which at the time was much admired. "In 1860 the Cocomero theatre at Florence was renamed, 'Teatro NiccoIini. " 187

It may be stated that the highest tone of Iyrical expression was given to Risorgimental tragedy by Alessandro Manzoni, and Romantic and national ideals lived once again through him and in the light of the Catholic faith. While Iellico and Niccolini, in their work, plunged them$185_{\text {Collis on-Morley, op.cit., p. } 257 .}$
$186_{\text {King, op.cit., p. I44. }}$
$187_{\text {Aurie Magnus (ed.), A Dictionary of European lit- }}$ erature (Iondon: George Rout Tedge \& Sons, Itd., 1926), p. 366 . 
selves with no heed for the metaphysical into the Iiving political struggle, "...Manzoni leaned towards a style which, even though inspired by reality, strove beyond it to a higher visjon of human destiny." 188 Because of this, his tragedies, Il conte di Carmagnola and Adelchi caused bitter disappointment to some of the liberals who were most closeIy concerned with the struggle. Manzoni was in a way far above the combat.

The Count of Carmagnola concerns the story of the hero who has married the daughter of Filippo Maria Visconti, and enters the service of the Venetian Republic-Viscontj.'s enemy. He wins the famous Battle of Maclodjo, but he is unjustly suspected of treachery, tried, and on May 5, 1432, is beheaded. Only in the solitude of his cell does the proud and gallant captain, who has been blinded by power, find Christian serenity and, realizing the futility of earthly ambition, accepts his unmerited death as a liberation.

It is much the same way with Adelchi, hero of the play of the same name, who, side by side with his father, Desiderio, is compelled to fight a war which he does not believe in, and re-discovers his own moral liberty when, mortally wounded and a prisoner, he casts aside all earthly interests and succeeds in attaining the peace of faith. In the two tragedies, the weak, humble, oppressed and defeated struggle

$$
{ }^{188} \text { Meccoli, op.cit., p. } 130 .
$$


against the mighty who move the wheels of history by vio.lence, crushing all rights and sentiments in their path; but it is the former in their obscurity and suffering who come nearest to the truth, according to Manzoni.

The Conte di Carmagnola and Adelchi when viewed as the Manzoni solution to the patriotic problem in the light of a kird of evangelic solution have the same basic theme: the uselessness of civil war, brother killing brother, and the impossibility of expecting salvation from a foreign power which arives out the occupying force, only to t ake its place in the process.

The description of the Batt]e of Maciodio in the chorus of Conte dj Carmagnola is a "...melancholy dirge in which the split among Italians is deplored."190 In the first chorus of Adelchi Manzoni reaffirms with deeply felt power the conviction that was slowly spreading among some liberals aftex the defeat of Napoleon and the Restoration that there was "...urgent need for Italians to conquer liberty by themselves and not to wait for foreign powers to do it." 191 But these appeals however sincere they were left a feeling of discomfort and bitterness because they exuded little confidence in the possibility of success. As time went on, there was more and more cause for some liberals to look to the theatre for hope as one of the instruments heralding of better days to come. But Manzoni does not give these pro-

189 W. P. Friederich, "Manzonj," Enciclopedia dello Spettacolo, ed. G. C. Sansoni, X (1956), p. 114 . 190 Meccoli, op.cit., p. 131. 191 Nartinengo-Cesaresco, op.cit., p. 104 . 
mises. In ract, Il Conte di Camagnola was performed ...only once in 1828 and Adelchi was put on in 1843 in Turin by the Royal Sardinian Compa ny, but they were both received somewhat tepidly, not only because of their slowness and lyric tone, but also because their 'spirit' was so vastly different frog 2 the spectators! anxious and elated state of mind.

There were many other theatre writers at this time-mall mediocre or worse in quality--flourishing around the principal ones discussed in this paper, and all repeating more or less in different disguise the same blueprint of tragedy, e.g., Francesco dall'Ongaro, a follower of Mazini; Ed... uardo Fabbri, one of Alfieri's discjples, etc. Angelo Brofferio, a left-wing member of the Piedmontese Parliament, was secretly entrusted with the task of writing a tragedy by Charles Albert. It was called Vitige re dei Goti. It was known that the King and Brofferio hated each other, and that the latter was hounded by the Piedmontese police, and yet for some yet unexplained reason, the King commissioned him-sub rosa, to write this play. "The play which was only produced in 1848, was banned by the censors, for it was a clear attack on Austria; it ends up with the cry, 'Iong live Italy!" "193

Plots and conspiracies against the tyrant and usurper, uprisings by the oppressed against the oppressor, people's revolts and so on, appear again and again in all these tragedies which are set mostly in medieval history because it

192 Magnus, op.cit., p. 370.

193 Kennard, op.cit., II, p. 198. 
was felt the real root of the moral and civil conditions of the Italian people was to be found there. The tyrants usvally were French or Spanish, and these were seen to represent the present occupiers--the Austrians. The conquered and the agitators were seen as prototypical of the Risorgimental fighters.

It is not surprising, therefore, that in 1842, the Duke of Modena announced a competition in. which prizes would be awarded to the two dramatic companies which mos $t$ successfully contributed to not 'causing in the mind of the spectator aversion or cogtempt in respect of the most worthy authorities.

The censors of the various states were continually occupied in re-reading the scripts of plays to be performed; they cut out a phrase here and there, and substituted this or that word. But on the whole it was futile work because gradually, beginning from the scattered and chance allusions, tragedy created its own coded language, its own atmosphere, its catalogue of subjects and situations which played upon emotions--passions--and did not necessarily involve any literary sophistication.

Viewed objectively and from the vantage point of the present, these works-all of them with but few exceptions-were destined to be artistically transient, because they were too obviously aimed towards propaganda. But it would seen, at least, that the writers worked at this end quite consciously; "...the theatre wanted to become a patriotic in-

194R. S. Holland, Builders of United Italy (New York: Holt and Co., 1908), p. 47. 
strument, and i.t did, in fact, become one of the most active forces promoting the national spirit." 195

The actors, too, were a living part of the movement, Some players on the stage took on vital roles in political life as well. One example was Gustavo Modena for whom the theatre was more than anything an instrument of civil action.

In 1829 Modena provoked an anti-Austrian display at Fadua when playing in Pellico's Francesca da Rimini. The audience was in an uproar by the play's end, and spilled out into the streets shouting anti-government slogans... Modena fought at Rimini, Ancona and Cesena; finally, in exile in Marseilles, has met Mazaini and joined the Young Italy Movement.

A strong political current runs through the bulk of Italian literature of the Risorgimento before 1848. "Italian Romanticism was essentially political, and the drama was no exception."197 However, after 1848 the oratory and patriotic usefulness of tragedy slowly dwindled, and dramatic literature gradually turned its attention towards social and humanitarian problems.

Even so, the theatre was still for the minority. Just before 1848 the ideal of independence which until then was fired by the passions of the very few, became a little nore of a people's movement. This is perhaps why tragedy and its function of rhetorical patriotism gradually changed over to

195 Kennard, op.cit., p. 199.

196 Meccoli, op.cit., p. 132.

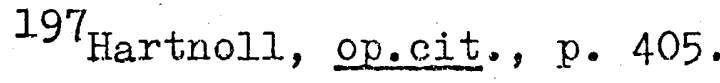


melodrama, such as Paolo Giacometti's II poeta e la ballerina, 1847. Melodrama, with its concems with social problems, when assisted by the immediate and universal link of music, could comminicate with larger audiences and establish a fal" broader mutual understanding.

As in Risorgimental drama when the most contentious witticisms in the tragedies were passed by word of mouth, so in Risorgimental music song fragments and lyxics spread in the same way. In the opera, they acquired a special significance because they frequently cloaked controversial aiIusions. And this series of changes, too, like those which occurred in the field of tragedy, originated quite by chance and their mutual development was uncertain.

Rossjni's last opera, Hilliam Tell, 1829, expressed a deeply-felt re-awakening which resul.ted in part from the persistent uneasiness and anxiety of the time. I'ell extols the vindicator of Swiss national freedom, and then possibility of political allusions in such a libretto are myriad. But his opera. was first performed in Paris, and it took several years to reach the Peninsula, and when it did, its grace and elegance tended to soften the political overtones and made it appear more of a French piece than ar Italian one. Yet the allusions were there and took on added meaning as time went on.

Again, Vincenzo Bellini's opera I puritani e i cavaliexi, performed for the first time in Paris," was enervated in its political allusive possibilities by its intrinsic grace; 
however, in time the opera gave

...the independence fighters $\partial$ verse which speedily became famous as an incitement to fight for 1848 and beyond caused clamorous incidents. $1988^{\text {to }}$

Though poetry may be said to be generally missing from Risorgimental tragedy, except for Manzoni's II conte di Carmagnola and Adelchi which tended to lose their force for the liberals because Manzoni in them "...tried to rise towards sublime abstractions of purest spirituality...," 199 poetry certainly may be said to be very much a part of Risorgimental opera, especially in the works of Giuseppe Verdi.

"The Italians-and especially Verdi--were particularly the masters of vocal music, or song." 200 And the opera houses at this time were one of the meeting places of life in Italy. No doubt, Verdi fully realized this fact.

Intermissions were long, food and drink were generally available and sometimes gambling men went to the opera for entegdainment and also to talk business and politics.

Verdi had a wide and balanced experience of both music and the drama. Dramatic characterizations and situations developed artistically and politically in Verdi's work from his Nabucco to Ia battaglia di Legnano, from 1842 to 1849-the culminating period of the Risorgimental opera--into a

$$
\begin{aligned}
& 198_{\text {Holland, op.cit., p. } 51 .} \\
& 199_{\text {Meccoli, op.cit., p. } 133 .} \text {. } \\
& 200_{\text {Sidney Finkelstein, Composer and Nation (New York: }}
\end{aligned}
$$
International Publishers, 1960), p. 9 .

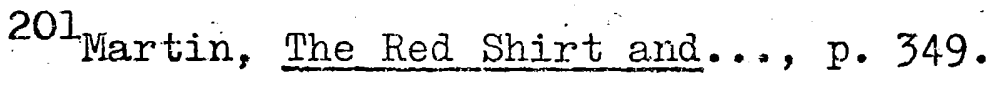


living and consistent entity supported by sometimes a crude, yet vigorous poetic force.

Verdi's poetic world has clear and precise fronttiers and his territory is restricted: it is the world of sentiments which comprises the elernents common to all men, and which thus causes the 'crowd' to be aware of itself and imbuger $2^{\text {it }}$ with the enthusiasm of this discovery.

Verdi's melodramas were mostly characterized by frenzied, rapid, concise action. With him, it may be said that the Italian Risorgimento was impatient to get under way. At the same time, mention ought to be made of the historical limitations of Verdi's music-dranas: their recourse to melodrama per se, "...such as the coincidences, the accidental changing of babies at birth, mysterious poisonings, the overused motif of love across the warring camps."203

Still, Verdi had an especial appeal to men of all ages and stations in life. The roots of Verdi's melody lie in Italian popular song, the band music he heard so often in childhood, and most of all, the melodic fund of his predecessors, such as Rossini, Donizetti, Bellini and a host of others.

Another influence on Verdi's musical career was the wealth of folk-songs which surrounded him. "Folk-song is the original melody of man; it is the musical mirror of the world." 204 Folk-music is the product of a race and reflects $202_{\text {Abraham, op.cit., p. } 79 .}$
$203_{\text {Finkelstein, op.cit., p. } 159 .}$
204 Julius Portnoy, Music in the life of Man (New York: Holt, Rinehart and Winston, 1963), p. 112 . 
feelings and tastes that are comnunal rather than personal. Verdi also incorporated elements of folk-song he-hat-heard in his young years into his operas. He saw the need for an operatic style of deeper psychological penetration than those of Bellini or Rossini-mone more varied and distinctive in human characterization and in its reflection of emotional conflict, than the other composers mentioned. Born of the peasantry, Verdi struggled all his life for the independence and the welfare of the peasant, in actuality, seeing the two as one.

All art creates primarily with human images. Thus in drama, opera, a playwright or composer sets actual human beings in motion and speaking. When the onlookers recognize some part of themselves in these images, they are caught up in the life on the stage. And through this power that the human images of art have, namely, of appearing to be not only something in the life of the artist taking objective form, but something in the lives of the onlookers, the playwright or composer can play upon their mind and emotions. When they go back to their daily lives, they are changed, because he has made his own discoveries of life their possession.

Verdi knew this very well, and made the mos $t$ of $i t$. "Verdi wrote tippy-toe conspirator music, alternating with loud crashes on the brass and drums."206 This approach, this technique gave to Verdi's operais and music an immediacy of appeal which was quickly communicated to his audience, but most difficult for the censor to isolate.

$$
\begin{aligned}
& 205_{\text {Finkelstein, op.cit., p. } 14 .} \\
& 206_{\text {Wartin, Verdi, His Music..., p. } 119 .}
\end{aligned}
$$


"The first display of Verdi's poetry and musical genius came with Nabucco, performed at Ia Scala, Milan, March 9, 1842."207 With Nabucco it is fair to say his artistic career began. The opera was an enormous success, and there were scenes of wild enthusiasm after Act I, an enthusiasm which grew even more fevered as the performance progressed.

The audience at the premiere was sent into a state of delirium by the Third Act chorus, 'Va, Pensiero sull'alj dorate,' and insisted on its being repeated. A law was in force in Milan forbidding encores; they were too frequently turned into demonstrations against Austrian rule. And 'Va, Pensiero' was pretty inflammatory stufe. It was easy for the Milanese governed by Austrians to see themselves as Jews suffering under the Babylonian yoke; they made the connection and made it vociferously. With this one chorus in an opera on a biblical. subject, Verdi immedia.tely and inadvertently became the composer of the Risorgimento 08 the movement towards a united and free Italy.

The story of Nabucco was purely Risorgimental. Ugo Foscolo and Niccolini had already used it. The story of the captive Jews provided startlingly clear symbol of the condition of the oppressed people of the Peninsula. How could the Milanese fail to respond to the pathos of "...Act III, Scene ii's, 'O mia patria si bella e perduta, o membranza si cara e fatal, ' and to Verdi's heartfelt setting of it?"209 From the opening of Nabucco until the unification of Italy nearly 30 years later, Verdi was to find himself

${ }^{207}$ Charles Osborne, Ihe Complete Operas of Verdi (New York: Alfred A. Knopf, 1970), p. 50.

${ }^{208}$ Ibid., p. $5 I$. ${ }^{209}$ Finkelstein, op.cit., p. 161. 
continually in trouble with the censorship, usually Austrian or Papal.

Nabucco was performed not only throughout Europe

...but in North, Central and South America as well. In Nilan it continued to be revived season after season. A.t its first revival in the autumn of 1842, only a few months after the initial eight performances, it was given 57 times during the season, creating a new record.

Verdj's next great opera of note, I Lombardi alla prima crociata, first performed at La Scala, Milan, Febru... ary 11, 1843, brought many complications-weven brought the censorship of the Church hierarchy into the production. Within a few months before the opening, the Archbishop Gaysrück of Milan--an Austrian--heard tell that the opera included what to him was a sacrilegious stage representation of the Sacrament of Baptism, and ordered the Chief of Police to ban its performance. The Chief of Police attempted. to persuade Verdi to compromise, but the composer refused to discuss the matter. Finally, the Chief agreed to allow the performance if the line "Ave Maria" was changed to "Salve Maria."

I Iombardi was played before a keyed-up audience, many of whom had queved for several hours to obtain seats. The evening was a triumph, and the police rule of no encores was broken again and again. The Milanese decided from the very beginnings of the opera that they were the Lombards, that the Holy Land they were defending was Italy, and that Saracens had a great deal in common with Austrians. When in the last act the Lombards were incited to

210 Gerhart Von Westerman (ed.), Opera Guide (New York: E. F. Dutton \& Co., Inc., 1968), p. 32 ? 
battle with the words, 'La Santa Terra oggi nostra sard' ('loday the Holy Iand will be ours), many of the audience spontaneously shouted 'Si' and there was an outburst of loud cheering.

The Risorgimental tenor of the opera, then, is apparent from the story itself as well as from individual phrases. The Iombard Crusade is comparable with the Crusade of the Italian people for their redemption. The audience quickly made the connection, and to the censor's sorrow repeated its loud enthusiasm for practically every chorus, performance after performance.

"Requested to write an opera for the la Fenice theatre, Venice, Verdi in 1844 composed the music for a libretto taken from Victor Hugo's farnous novel, Hernani." 212 When this opera was first performed in Venice the police found the scene of the conspirators in the Tomb of Charlemagne "...too provocative and closed the theatre for fear it might lead to a popular uprising against the Austrians." 213 The audience, and particularly during the later performances, joined in the fiery and stirring warrior's chorus which follows the opera's climax. In August, 1846, the opera was again performed at the Communal theatre in Cesena. A few weeks previously, on July 17, Pope Pius IX had granted an amnesty, re-awakening liberal hopes for a new and broader line of

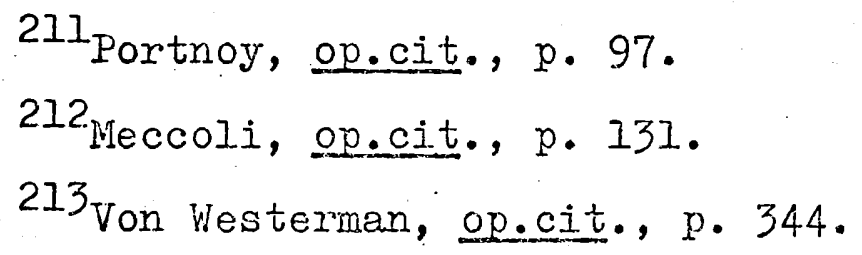


policy.

Representatives of the townsfolk of Cesena requested the Commissioner for Public Performances to substitute an entire section of Act III with another which sings the praises of the Pontiff. And on some other occasions the line, 'Nay there be glory and honox to Charlemagne' was sung: 'Glory and honor to Pius IX,' or 'Glory and honor to Charles Albert.'

Ernani grew in popularity after the first performances. When it was revived two montho later at another Venetian theatre, the Teatro San Benedetto with even greater success than at Ia Fenice, "...people left the theatre after the periormance cheerfully humming its tunes." 215

Although the characters in Ernani may not strike us today as particularly interesting or subtle in their behavior, they did provoke Verdi to paint them in strong musical colors. The opera appears to mark an advance on Nabucco and I Lombardi in that Verdi's musical characterization became more assured.

The elegant irony of Hugo's Hernani from which the libretto was taken vanished in its transition to Verdi's Ernani, and only 㧽e full-bodied Romanticism remained. It is enough.

One of Verdi's next operas--Giovanna d'Arco--is thought to be of really mediocre calibre, both in libretto as well as in musical score, despite the fact that the opera is based on one of Schiller's greatest plays, Jungfrau von Orleans.

214 osborne, op.cit., p. 72 .

215 Ibid., p. 83.

216 Martin, The Red Shirt and..., p. 91. 
Very little of the libxettist's dialogue is a direct translation of Schiller. Juaged purely on its own terms, wi.thout reference to Schiller or history, Giovanna d'Arco may be said to be average stock. Even so, the opera drew the censor's ire several times. In one instance

.. in Palermo, two years after its opening at Ia Scala, 1845, police objections to the subject necesitated the music being fitted to a new libretto with the title of orietta di Lesbos in place of Giovanna d'Arco.

Verdi's Attila, first performed in Venice's Ia Fentce theatre, 1846, elicjted much audience enthusiasm and provid-ed some catchy slogans and phrases for the liberal cause. Within several states of the Peninsula, almost the entire opera became a kind of battle cry, at least, it connoted liberal sentiments which were quickly taken up by those who were activists in the struggle for liberation. In instance after instance, up to 1848 and after, until Italy was finally unified in 1870

... when the audience saw the Huns appear on the Adriatic shore, it burst into cries of 'Italia, Italia.' Some of Solera!s [ibrettist's] lines were passed directly into the language, such as when the Roman says to Attila, 'Avrai tu l'universo, resti I'Italia a me' (You take the universe, leave Italy to me), Act II, Scene ii. Verdi's music for the phrase was particularly happy and the duet between Attila, bass, and the Roman, baritone, in which the words are a recurring phrase is vibrantly alive and with a masculine vigor that was peculiarly Verdi's. Invariably the audience shouted back at 2 然e stage, 'A noj I'Itailia' (Italy for us).

${ }^{217}$ Herry A. Simon (ed.), The Victor Book of the Opera (13th ed. rev.; New York: Simon \& Schuster, 1949), p. 189. 218 Martin, Verdi, His Wusic..., p. 3.67. 
That the censors allowed the line, or almost any part of the libretto for that matter to pass, seems most extraoxdinary. But of course, at that time the Peninsula's censorship varied from state to state and was, paradoxically, least serious in those two provinces which Austria actually occupied as its dependent Kingdom of Lombardy-Venetia. The presence of its army there gave its government confidence so that it was less easily alarmed than the smaller states, such as Modena or that of the pope. They had to rely on. calling in the Austrians which took time and left a hazardous interim. But perhaps more important was that the censorship in Milan and Venice was intended to support a foreign administration; elsewhere, such as in Rome or Naples, it was intended to support a native administration. The difference had a marked effect on the loyalty and diligence of those "Italians" who worked in the various censor's offices. The censors recognized that a change in government in Naples, for example, would cost them their position, but a change in government in Milan would result most probably in simply costing the Austrians their jobs. "It is not surprising then that the greatest trouble Verdi had with censors occurred in Naples." 219

The Risorgimental period of Verdi's work ends with the first performance of La Battaglia di Legnano in Rome's Argentina theatre, January 27, 1849. Ia battaglia is an opera with a purpose. Parts of Verdi's earlier operas had fre-

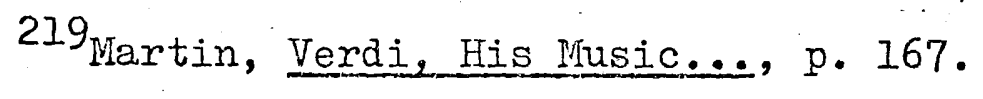


quently been taken up by the fighters of the kisorgimento, but this time "...the composer had given the movement its own opera. It was his contribution to Italy's future as a united nation." 220

There were other operas, too, between Attila and La battaglia, such as I due Foscari, Alzira, MacBeth, I Masnadieri and II Corsaro but these are definitely not among Verdi's greatest works; however, the frequency of political allusions in these operas is so great that Verdi was even accused of exploiting the pretexts of the patriots.

In truth, Verdi succeeded in creating a splendid popular theatre, where audiences gradually came to resemble a vast meeting which, in itself, could 2 ge transformed into a reason for immediate action.

In spite of Austrian censorship, Verdi had managed to include at least one chorus about "Ia Patria,"or one which by allusion referred to it, in many of his.operas previous to Ia battaglia, and many patriotic Italians in many states of the Feninsula had taken these up as kind of national hymns. "In a country where so many men were illiterate those great swinging choruses with their patriotic sentiments were an important influence." 222

In actuality, opera triumphed throughout the whole period in which patriots fought for Italian unity. Its tunes were heard over and over again in the streets and squares.

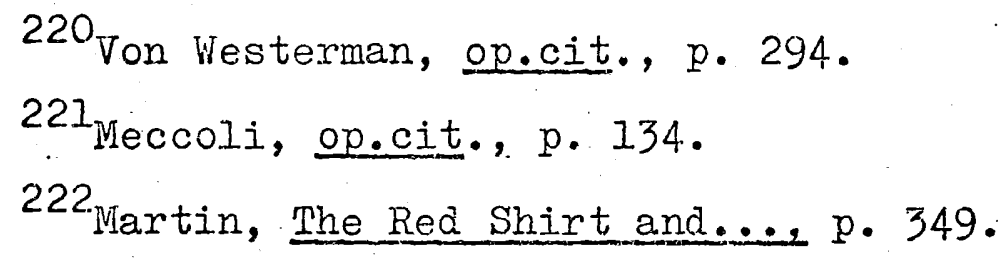


Verdi brought to Italian opera of the 1840's a nervous energy, a kind of brooding Romanticism and a rough vigor reminescent of the peasant which succeeded one another with astonishing rapidity. All his operas on their different levels are very enjoyable in performance, and the fact that they were at the time in varying degrees associated with the cause of a united and free Italy increased their popularity immensely. His music and much of the librettos stirred the passions of the people, and this is why, perhaps, that durm ing the performances of his works, the more violent phrases became an agreed signal for patriotic displays. "The music was the biggest worry for the censors and the police."223

It may be said without overstatement that the Italian theatre, in spite of its narrow range, from Pellico's veiled forebodings to Verdi's mighty choruses, symbolizes truly an epic song of Italy.

\section{ATIEINDANCE AND PERFORIIANCES}

In determining the extent of the theatre's effectiveness in helping to form the Italian national spirit, it is necessary to have some idea of the attendance and frequency of performances. Unfortunately, there is very little information available in this connection; however, what there is may be gleaned from the size of theatres and opera houses,

223 R. Vaughan Williams, National Music (Iondon: $0 x-$ ford University Press, 1963), p. 183. 
population figures, types of people who made up the audiences and some information on the number of performances.

One author affirms that "...theatre was very popular everywhere in Italy at that time." 224 There can be little doubt of this because, as stated above, the theatre had (and always will have) an immediate, direct appeal tao all levels, and it did not require for its understending or enjoyment that the audience be necessarily literate or possess an aesthetic sophistication-the drama, and particularly music, communicate in a universal language.

When Nabucco re-opened in the autumn at Ia Scala, it was...even rnore successful than in the spring. Between 13 August and 4 December it had 57 performances, which at the time was a record for a single season, and it is said that the chorus, 'Va Pensiero,' was encored at every one...The number of performances is particularly impressive in that Milan in 1842 was still a city of less than 150,000 inhabitants. Ia Scala had been renovated and the seating changed several times since then until today it seats about 2300 , not including the standing room; in 1842 with a top gallery since eliminated it may have held about 2600. So that it is possible that something like 20,000 mor seats were sold to Nabucco in its first year than there were inhabitants in the town. Visitors undoubtedly came but probably not many. There were still no rail connections, and travel by coach was uncomfortable. Besides the tradition of the time was thatt the opera rather than the audience traveled.

It was customary, then, for some opera-goers to attend more than one performance. The men of Milan, for example, used to meet in coffee shops or at the theatre where

$$
\begin{aligned}
& { }^{224} \text { Hearder, op.cit., p. } 131 . \\
& 225 \text { Martin, Verdi, His Music..., p. } 107 .
\end{aligned}
$$


the intermissions were long and the performances as much of a social as a musical event. Obviously, when a man went for the third or fourth time in a month to a performance, say of Nabucco, he did not feel pressed to break off a conversation in the foyer to be in his seat for the start of any act.

The conversations ranged from art to penal reform, and although the groups sometimes had a specific bias to them, they just as often did not. The tradition was that all men of culture mixed together freely and deliberately in 2 geder to exchange, polish and enrich their ideas.

There wass a great deal of socializing and conviviality going on before, during and after the performances, for when the composer Berlioz, for example, went to hear Donizetti's I'elisir d'amore at the Camnobiano theatre, Milan, 1834

...he found the theatre full of people talking at the tope of their voices with theix backs to the stage. But talking at the opera and at concerts seems to hazhe been then a common practice all over Europe.

There were theatres all over the Peninsula, even in some of the smaller cities, too. However, the great theatres-for performances of both opera and drama-were at Venice, Vicenza, Genoa, Turin, Milan, Bologna, Florence, Padua, Pisa, Naples and Rome. "To these elegant structures the elite and the commonalty came to converse and ogle as well as to hear the opera or the play."228 One author gives a good indication of the great amount of artistic activity at one theatre

226 Martin, Verdi, His Music..., p. 112. 227 Abraham, op.cit., p. 15.

228 Will and Ariel Durant, Rousseau and Revolution (New York: Simon and Schuster, 1967), p. 220. 
center:

La Quarconia was the most popular theatre in Florence. In the same night, a tragedy, a farce, a ballet, acrobatics, pantomime and a violin concert were given. In the pit families would eat heartily, reserving the orange peels and simizizgr projectile for use against unpopular actors.

At many of the performances, especially for opera premieres, crowds would gather outside the theatre early in the afternoon, waiting for the evening performance. They would bring sandwiches and wine, and by evening there were us-ually more than could be admitted. The price of admission ranged "...from what today would be equivalent to a few cents for the pit area, to two or three dollars for the reserved stalls or boxes." 230 The prince range, then, was within the reach of just about everyone, and this applied to both drama and opera.

229 Kennard, op.cit., p. 176.

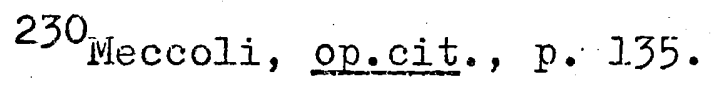




\section{CHAPTER III}

\section{CONCJUSION}

\section{SUMMARY}

Italian drama, from Alfieri to Niccolini, generally speaking, was verbose, badly versified and constructed, and often oriented towards Iyricism at the expense of good and true characterization and story development. These plays when read today (they are never performed) seem belabored and boring works of historical curiosity only. Yet much of the drama had appeal for many of the then liberals who yearned for freedom from the oppressor and for Italian independence and unity. Iiteracy or intellectual sophistication on the part of the audience was not necessarily part of the process of appreciating the political connotations. Censorship--mostly of the government, but sometimes also of the Church--stepped in and blunted efforts to perform or at least caused changes to be made in the script. Though the printed word as such was censurable, the scripts often contained aIlusions-whether by intention or accident--to the conditions on the Peninsula, and these allusions--so quickly picked up by portions of the audiences and rapidly communicated to others--were not censurable. Words, phrases, etc., which seemed so innocuous in context, could be taken out of it and 
made into patriotic catchwords and slogans, anti-government in meaning with Liberal overtones that presaged the Risorgimental battles to corne.

The same is true of operam-only more so--for music has an even greater and more immediate appeal to the emotions and passions of its audience. Its universal appeal per se, the natural muscular response it engenders in reaction to its tempo and melody, plus a libretto that might contain characters, situations or dialogue that coula be indirectly related to the conditions on the Peninsula-.-.all add up to pos... sible situations recognizable to the audience. Moreover, the opera--especially Verdi's

... were based on a simple rhythm to which everyone from the musical aristocrat to the sinplest peasant could have much the same musical and muscular response. The opera tended to be a great leveler, binding all the audience, into a single unit that appreciated, rocked and hurned together. This is one reason why some musical aesthetes of the time found Verdi's music vulgar, there seemed so little room in it for subtle musical effect and appreciation. But for the great mass of people, particularly the Italians, it made going to the opera even more of a communal experience which partly explains why Verdi's choruses became such popular battle songs ${ }_{\text {independence. }}$ the Italian struggle for unity and

\section{CONCLUSIONS}

The theatre--drama and opera--1830-1848, was one of more dynamic and immediate forces working on the liberal minority--directly or indirectly--in the formation of the

23I liartin, Verdi, His Music...., p. 207. 
national spirit.

It is most aifficult to determine--if not impossible-the precise extent of the role of the theatre in Italy in the creation of that spirit. However, from the foregoing, there can be little doubt that it was a much greater force, for example than the press. Though the theatre labored under its own handicaps, e.g., of one form or another of censorship, of being constricted by the fact that theatres and opera houses were required for perfor nances, and these were only to be found in the cities where but a small minority of the population resided; nevertheless, it can be Jogically inferred that the theatre for the many urban dwellers was a potent influential factor which, judging from the many demonstrations after pexformances and the many phrases that entered the language from the theatre at this time, contributed to the development of the national spirit. This can also be inferred logically-if for no other reasons-because the theatre was a focal center of Italian city-life, and because of the fact that to understand and enjoy the works of the theatre--whether meritorious or otherwise--did not necessarily require literacy, educational background or profound aesthetic sophistication on the part of the audience. Rather, it demanded an intensity of feeling and an acute, emotional, passionate response, qualities which have always appeared to be part of the nake-up of the Italian people. When this intensity of feeling was coupled to the Iiberal message inherent in many of the works, a message of hope was 
communicated to the Italians who felt themselves oppressed. The audience was quick to understand the "code" language and to pick up and repeat phrases with political overtones-much to the sorrow of the authorities. Therefore, there is considerable indirect evidence to conclude that the theatre, 1830-1848, was a substantial factor in the formation of the Italian national spirit. 


\section{BIBLIOGRAPHY}

\section{GENERAI}

Albicini, C. Politica e storia. Bolognia: Zanichelli, 1890.

Albrecht-Carrie, Rene. Italy from Napoleon to Prussolini. New York: Columbia University Press, 1950.

Arti, Frederich E. Reaction and Revolution. Nev York: Herper and Row, Publishers, 1934 .

Dalbo, Cesare. Delle speranze ditalja. Capolago, 1844.

Berre, Stringfellow. Mazzini. New York: Henry Holt and Co., 1935.

Berkeley, G. F. F. Italy in the Making, 2848; Iondon: Cambride University Press, 1940).

Biagi, Guido (ed.). Ia vita Italiana nel Risorginento 18151831. Firenze: R. Bemporad and Figlio, 1897.

Bowle, John. Politics and Opinions in the 19 th Century. New York: Oxford University Press, 1964.

Cappelletti, Iicurgo. Storia del Carlo Alberto e del Suo Regno. Milano: Voghera, 1891.

Capponi, Gino. Scritii editi e ineditti. Florence: Earzoni, 1877 .

Chápman. Eunice. Italy--A Survey of Italian Iducation. Hastings, Nebraska: Hastings Colle êe Fublications, 1962.

Crankshaw, Edward. The Fall of the House of Habsburg. New York: Viking Press, 1966.

Crawley, C. W. (ed.). The New Cambridge Modern History. Camoridge: University Press, 1965.

Croce, Benedetto. History of Europe in the 19th Century. New York: Harcourt Brace and Co., 1.933.

Orow, John A. Italy--A Journey through Time. New York: Harper and Row, Publishers, 1965. 
Cubberley, Bllwood P. A History of Education. Boston:

Houghton Miffiin Co., 1948.

Davidson, Marshall B. (ed.). The Age of Napoleon. New York: American Heritage Publishing Co., 1963.

D'Azeglio, Massimo. I miei ricordi. Iranslated by E. R. Vincent. London: A. F. Dutton Co., 1894. - Proposta d'un programma per l'opinione nazionale Italiano. Firenze: Le Monnier, 1847.

De Gregorio, F. Serao. Gli albori della conscienza nazionale e del Risorgimento Italiano fino al 1815 . Roma: Editrice Corso, 1949.

Delzeli, Charles F. (ed.). The Unification of Italy. New York: Holt Rinehart and Winston, 1965 .

Durant, Will and Ariel. Rousseau and Revolution. New York: Simon and schuster, 1967.

Giovagnali, Rinaldo. Storia politica d'Italia. Milano: Dottor Francesco Vallardi, 1937.

Hearder, H. and Valley, D. P. (eds.), A Short History of I.taly. New York: Cambridge University Fress,

Hobshawn, E. J. The Age of Revolution, 1789-1848. New York: New American Library, 1962.

Holland, R. S. Builders of United Italy. New York: Holt and Company, 1908.

Holtman, Robert B. The Napoleonic Revolution. New York: J. B. Lippincott Co., 1967.

Howe, Irving. Politics and the Novel. Greenwich, Connecticut: Fawcett Publications, $1.95 \%$.

Jamison, E. M. et al. Italy--Medieval and Modern: A History. Oxford: At the Clarendon Press, 1919.

King, Bolton. A History of Italian Unity. London: James Nisbet and Co., Itd., 1899.

Kissinger, Henry A. A World Restored. Boston: Houghton Mifflin Co.; 1957.

Kuntz, Coiby. European Authors. New York: H. W. Wilson Co. 1967. 
Iipson, E. Europe in the 19th Century. New York: The Macmillan Co., 1962 .

Martin, George. The Red Shirt and the Cross of Savoy. New York: Dodd Mead \& Co., 1969.

Martinengo-Cesaresco, J. Italian Characters. Iondon: Seeley \& Co., It $\mathrm{t} ., 1902$.

Namier, Iewis. The Revolution of the Intellectuals. New York: Doubleday and Co., 1.964.

Nassau, William, Sr. Journals Kept in France and Italy. London: 1871.

Newton, Eric. The Romantic Rebellion. New York: St. Martin's Press, 1962 .

Noether, Emiliana Pasca. Seeds of Italian Nationalisin. New York: Columbia University Press, 1951.

Omodeo, Adolfo. Difesa del Risorgimento. Roma: Giulio Einaudi Editore, 1955.

Packe, Michael St. John. The Bombs of Onsini. Iondon: Secker and Warburg, 1957.

Paleologue, Maurice. Cavour. New York: Harper and Bros., 1927.

Pareto, Magliano. Descrizione di Genova e del Genovesato Genoa: 1846.

Robertson, Priscilla. Revolutions of 1848. New York: Harper Torchbooks, 1.952.

Salvadori; Massimo. Cavour and the Unification of Italy. Princeton: D. Van Nostrand Co., 1961.

Salvatorelli, Iuigi. Concise History of Italy. New York: Oxford University Press, 1938.

Salvemini, Gaetano. Mazzini. Stanford: University Press, 1957.

Schroeder, Paul W. Metternich's Diplomacy at Its Zenith. Austin: University of Texas Press, 1968.

Sforza, Carlo, Count. Contemporary Italy. New York: E. P. dutton Co., 1944.

Sinith, Denis Mack. A History of Sicily. Vol. III: Modern Sicily. New York: Viking Press, 1968. 
Smith, Denis Mack. Italy: A Modern History. Ann Arbor: The University of Wichigan Press, 1959.

New York: (ed.) $\frac{\text { The Making of Italy I796-1870. }}{\text { Harper and Row Publishers, } 1968 .}$

Spellanzon, Cesare. Storia del Risorginento e dell'unita. Vol. II: Da dopo i moti del 1820-21 alla elezione di papa Pio IX 1846. Mílano: Rizzoli. and Co., 1934 .

Strachey, Marjorie. Mazzini, Garibaldi and Cavour. New York: Stackpole \& Sons, 1938.

Sprigge, Cecil J. S. The Development of Modern Italy. New Haven: Yale University Press, 1899.

Stillman, W. J. Union of Italy, 1815-1895. Cambridge: Cambriage University Press, 1899.

Taylor, A. J. P. From Napoleon to Lenin. New York: Harper Torchbooks, 1952.

- The Habsburg Monarchy. London: Hamish Hamilton Co., 1948.

Thayer, William Roscoe. The Iife and Times of Cavour. Iondon: Constable \& Co., Ltd., 1911.

Trease, Geoffrey. The Italian Story. New.York: Vanguard Press, 1963.

Irevelyan, George M. A Short History of the Italian People. Lond on: George Allen \& Co., Itd., 1920.

- The Iife of Macaulay. Iondon: Iongmans Green Co., 1932.

Volpe, G. Italia moderna, 1815-1915. Firenze: Sansoni, I.1943.

Walker, Mack, (ed.). Metternich's Europe. New York: Harper and Row, Publishers, 1962.

Whitbley, Charles. Political Portraits. Iondon: MacMilian and Co., 1917.

Whyte, Arthur J. Evolution of Modern Italy. Oxford: Basil Blackwell Co., Ltd., 1950.

Wicks, Margaret C. W. The Italian Fixiles in Iondon, 18161848. Freeport, New York: Books for library Press, Inc., 1937. 
Woodward, W. H. Desiderus Erasmus: Concerning the Aim and Methods of Education. New York: Columbia University Press, 1904.

BOOKS ON JOURNALISN

Bird, George I. (ed.). The Press and Society. New York: Prentice-HaII, 1951.

Boynton, H. W. Journalism and literature. New York: Houghton Mifflin Co., 1904.

Brofferio, Angelo. Messaggero Torinese. Turin: 1847.

Caddeo, Rinaldo. Ie edizioni di Capolago, 1830-1853. Niilano: Valentino Bornbiani, Editore, 1934.

Cezzaminj-Mussi, Francesco. Il giornalismo a Milano. Mi..ano: Farniglia Meneghina, Editrice, 1934.

Cordani, Antonio (ed.). Pagine inedite del Conciliatore. Milano: Tipografia Condani, 1930.

Correnti, Cesare. I'Austria e la Lombardia. Capolago: Melchiorre Gioja, 1840.

Flint, Leon N. The Conscience of the Newspapex. New York: D. Appleton-Century Co., 1925.

Messaranti, Iullo. Cesare Correnti. Rome: Forzani, 1890.

Olson, Kenneth E. The History Makers. Baton Rouge: Iouisiana State University Press, 1966.

SaImon, Tucy NI. The Newspaper and the Historian. New York: Oxford University Press, 1923.

BOOKS ON THE THEATRE

Abraham, Gerald. A Hundred Years of Music. Chicago: Aldine Publishing Co., 1964 .

Baret, Sylvia et al. Aspects of the Drama--A Handbook. Boston: Iittle Brown \& Co., 1962.

Brockett, Oscar G. The Theatre-An Introduction. New York: Holt, Rinehart and Winston, Inc., 1969.

Cippico, Antonio. The Romantic Age in Italian Iiterature. Lond on: Blackwell \& Co., Ltd., 1918. 
Clark, Barrett H. (ed.). World Drama. New York: Dover Puklications, 1933.

Collison-Morley, Lacy. Modern Italian Literature. New York: Little Brown \& Company, 1912.

Colquhoun, Archibald. Manzoni and His Times. Iondon: J. M. Dent and Co., Itd., 1954.

Costetti, Giovanni. Il teatro Italiano nel 1800. Milano: Capelii, 1881.

D'Anccna, Antonio. Orjgini del teatro Italiano. Turino: Bocca, 1891.

Dannreuther, Edward (ed.). Oxford History of Music. VI: The Romantic Period. Oxford: At the Clarendon Fress, 1905.

De Sanctis, Francesco. Saggi Critici. 8th ed. revised. Na.poli: Morano, 1893.

- The History of Italian Iiterature. Translated by Joan Redform. New York: Basjo books, Inc., 1931.

Finkelstein, Sidney. Composer and Nation. New York: International Publishers, 1960.

Freedley, George and Reeves, John A. A History of the The= ater. New York: Crown Publishers, 1941.

Grillo, Ernesto N. G. Studies in Modern Italian Iiterature. Glascow: Jackson and Wyle, 1930.

Hartnol], Phyllis (ed.). The Oxford Companion to the Theatre. Iond on: Oxford University Press, 1957.

Hatlin, Theodore W. Drama--Principles and Plays. New York: Appleton-Century Crofts Co., 1967.

Kennard, Joseph Spencer. The Italian Theatre. New York: William Edwin Kudge Co., 1932.

Lang, Pauz Herry. Music in Western Civilization. New York: W. W. Norton \& Co., Inc., 194.1.

Martin, George. Verdi, His Music, Iife and Times. New York: Dodd Mead and Co., 1963.

McKinney, Howard $\dot{D} .$, and Anderson, W. R. Music in History. New York: American Book Co., 1940. 
Neccoli, Domenico. Il Risoreimento Italiano nel teatreo e nel cinema. Roma: Edi talia, 1961.

Osborne, Charles. The Complete Operas of Verdi. New York: Alfred A. Knopf, 1970.

Pellico, Silvio. Francesca da Rimini. Translated by E. A. Bowring. New York: Dover Iublications, 1933.

Portnoy, Julius. Music in the Iife of Man. New York: Holt, Rinehart and Winston, 1966.

Russo, Luigi. Storia della letteratura Italiana. Firenze: La Nuova Italja, 1957.

Sansone, Antonjo. Storia della Jetturatura Italiana. Palermo: Tipografia Giomale di Sicilia, 1892.

Seashore, Carl E. Psychology of Music. New York: McGraw Hill. Co., 1938.

Simon, Henry W. (ed.). The Victor Book of the Opera. 13th edition revised. New York: Simon and Schuster, 1949.

Vincent, E. R. Byron, Hobhouse and Foscolo. London: Cam-. bridge University Press, 1949.

Vittorini, Domenico. High Points from History of Italian Literature. New York: David WcKay Co., 1958.

Von Westerman, Gerhart (ed.). Opera Guide. New York: E. F. Dutton and Co., Inc., 1968.

WajI, Bernard. Alessandro Manzoni. New Haven: Yale University Press, 1954.

Werfel, Franz and Stefan, Paul (eds.). Verdi: The Mian in His Letters. New York: Fischer Publications,

Wilkins, Ernest Hatch. A History of Italian Literature. Cambridge: Harvard University Fress, 1966.

Williams, R. Vaughan. National Husic. Iondon: Oxford University Press, 1963. 


\section{ARTICLES AND PERTODICAISS}

Baldensperger, Francesco and Friederich, W. P. "Niccolini," Enciclopedia dello spettacolo. ed. G. C. Sansoni. XI (1956), p. 418-420.

Battaglia, Giacinto. "Ai lettori ed ai collaboratori," Rivista europea, III, pt. I (1840), vi-vii.

Bergin, Thomas G. "Reflections on a Centennial: The Italian Risorgimento," The Yale Review, XXXII (Sumner, 1961), p. 491.-503.

Calvi, Gottardo. "Notizie letterarie della Toscana," Rivista europea, III, Pt. 2, (1840).

Cavour, Camillo. "Des chemins de fer en Italie, par le comte Petitti," Revue Nouvelle, (May 1, 1846).

Cecchetti, C. "Ugo Foscolo," The New Catholic Encyclopedia, ed. William J. MacDonald, V (1967), p. 312.

Fanti, Aristide. "Education in Italy," A Cyclopedia of Education, ed. Paul Monroe, III (1912), p. J12119.

Fattorello, Francesco. "Giornale," Enciclopedia Italiana ed. Giovanni Gentile, XVII (1933), p. 323-331.

Friederich, W. P. "Manzoni," Enciclopedia dello spettacolo. ed. G. C. Sansoni, X (1956), p. 119-120.

Istituto centrale di statistica. Annuario Statistica. Roma: (I955).

Montano, R. "Manzoni," The New Catholic Encyclopedia, ed. William J. NacDonald, VIII (1967), p. 456-457.

Mazzini, Giuseppe. "Italy, Austria and the Papacy," Young Italy. Iond on: 1845.

Nicholson, Harold. "The Romantic Revolt," Horizon, III, No. 5, (Way, 1961), p. 48-55.

Mazoyer, Louis et al. "Italian Unification," Iarousse Encyclopedia of Modern History ed. Marcel Dunan $(1964)$.

Perella, N. J. "Italian Literature," The New Catholic Encyclopedja, ed. Willian, J. MacDonald, VII (1967), p. $24.5-251$. 
Phimb, J. H. "The Grand Tour," Horizon, II, No. 4 (Nov I, 1959), p. 73-104.

Pulgram, E. "The Tongue of Italy," Encyclopedia Britannica, ed. A. J. DeVi.to, III (I968), p. 289-294.

Rossi, Joseph. "The Distinctive Character of Italian Romanticism," The Modern Language Journal, XXXIX, No. 2 (February, 1955), p. 59-64.

Newsweek. "Talking Like a Native," March 9, 1970, p. 58.

Salamone, A. W. "The Risorgimento Between Ideology and History; the Political Myth of 'Rivoluzione Mancata, " American Historical Review, IXVIII, No. 1. (0ct, 1962), p. 38-45.

\section{REPORTS}

Bowring, John, Sir. Report, 1830. A report by Sir John Bowring, traveler and writer who visited Italy in the 1830's and reported on the illiteracy, ignorance, superstition, hostility to innovation and the "universal isolation" of the peasantry.

Scarangello, Anthony A. Progress and Trends in Italian Bucation. U. S. Dept. HEW, U. S. Govt. Printing Office (I964).

\section{REFERENCE WORKS}

Gassner, John and Quinn, Edward (eds.). The Reader's Encyclopedia of World Drama. New York: Thomas CroWeII Co., 1969.

Gove, Philip Babcock (ed.). Webster's Ihird New International Dictionary. Springfield, Massachusetts: G. and C. Merrian Company, 1965.

Langer, William (ed.). Encyclopedia of World History. Boston: Houghton Miffilin Co., 1968.

Nagnus, Aurie. A Dictionary of European Iiterature. Iondon: George Routledge and Sons; Ltd., 1926.

Ward, A. W. (ed.). Cambriage Hodern History, X: The Restoration. New York: The Packilian Co., 1911. 